\title{
Bedside clinical and ultrasound-based approaches to the management of hemodynamic instability - Part I: focus on the clinical approach: Continuing Professional Development
}

\author{
André Denault, MD, PhD • Annette Vegas, MD • \\ Colin Royse, MD
}

Received: 6 March 2014/ Accepted: 18 June 2014/Published online: 29 August 2014

(C) Canadian Anesthesiologists' Society 2014

\begin{abstract}
Shock is defined as a situation where oxygen transport is inadequate to meet the body's oxygen demand. An understanding of the mechanism(s) of reduced cardiac output, a determinant of oxygen transport, is crucial in order to initiate appropriate therapy to manage shock.
\end{abstract}

This Continuing Professional Development module is the first in a two-part series on the management of patients with hemodynamic instability. In this module, the emphasis is placed on the clinical aspects of shock including an introduction to selected features of echography. The second module, to be published later, will more extensively focus on the bedside ultrasound evaluation of patients. Ce module de développement professionnel continu est le premier d'une série de deux sur la gestion des patients ayant une instabilité hémodynamique. Dans ce module, nous insisterons sur les aspects cliniques du choc, y compris une introduction à certaines caractéristiques de l'échographie. Le second module qui sera publié ultérieurement abordera de façon plus complète l'évaluation échographique au chevet des patients.

Electronic supplementary material The online version of this article (doi:10.1007/s12630-014-0203-0) contains supplementary material, which is available to authorized users.

A. Denault, MD, PhD ( $)$

Department of Anesthesiology, Critical Care Division, Montreal Heart Institute, Université de Montréal, 5000 Bélanger Street,

Montreal, QC H1T 1C8, Canada

e-mail: andre.denault@umontreal.ca

A. Denault, $\mathrm{MD}, \mathrm{PhD}$

Critical Care Division, Department of Medicine, Centre

Hospitalier de l'Université de Montréal, Montreal, QC, Canada

\section{A. Vegas, MD}

Department of Anesthesiology, Toronto General Hospital, University of Toronto, Toronto, ON, Canada

C. Royse, MD

Department of Surgery, The University of Melbourne, Parkville, VIC, Australia
Combining the concept of venous return with the ventricular pressure-volume relationship is a useful method to appreciate the complex circulatory physiology of shock. Clues from the patient's history, physical examination, and key laboratory tests, along with the careful inspection of hemodynamic, electrocardiographic and respiratory waveforms can help with the identification of the etiology and mechanism(s) of shock. Following verification of the arterial pressure, general resuscitation can begin, and more specific treatment can be undertaken to manage shock. If the patient is unresponsive to these measures, bedside ultrasound can then be performed to ascertain more detail regarding the mechanism(s) and etiology of shock.

Purpose To develop an approach to the management of the hemodynamically unstable patient.

Principal finding Not applicable.

Conclusion Not applicable.

Objectives of this Continuing Professional Development (CPD) module:

After reading this first module, the reader should be able to:

1. Identify the three determinants of venous return.

2. List the various etiologies of shock using the concept of venous return.

3. Correlate the determinants of venous return to the ventricular pressure-volume loop and the assessment of the inferior vena cava.

4. Recognize certain aspects of the hemodynamic waveform (arterial pressure, central venous pressure, 


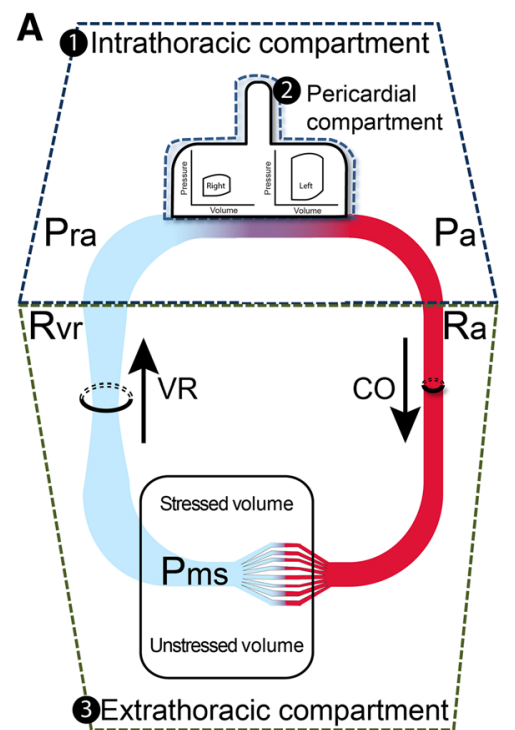

Fig. 1 The circulatory system and function curves. A) The circulatory system is a closed circuit consisting of arterial (red) and venous (blue) components, with $70 \%$ of the blood volume in the venous system. There are three compartments: 1) intrathoracic, 2) extrathoracic or abdominal, and 3) pericardial, which includes the heart. Venous return (VR) depends on the gradient between the mean systemic venous pressure (Pms) and the right atrial pressure (Pra). It is inversely related to resistance to venous return (Rvr). The Pms is determined by the distribution of total blood volume between the veins and the arteries and venous compliance. The Pms is determined mainly by the stressed volume (about $30 \mathrm{~mL} \cdot \mathrm{kg}^{-1}$ ), which is only a portion of the venous reservoir. The largest portion is unstressed volume. $\mathrm{Pa}=$ arterial pressure; $\mathrm{Ra}=$ arterial resistance; $\mathrm{CO}=$ cardiac output. $\mathrm{B}$ ) In the closed system, venous return (VR) must equal cardiac output (CO) and can be described with function (pressure-flow) curves. The cardiac function curve (or Starling curve) depicts the relationship between $\mathrm{CO}$ (dependent variable) and right atrial pressure (Pra) (independent variable). As Pra increases, $\mathrm{CO}$ will increase proportionally until a plateau is reached when the heart becomes overdistended. The VR curve shows the association between VR (dependent variable) and Pra (independent variable), but as an inverse relationship; an increase in Pra produces a decrease in VR. The $\mathrm{x}$-intercept is the mean systemic venous pressure (Pms), the pressure in the system when CO and VR are zero or the heart is stopped. The slope of the curve is a function of resistance to venous return (Rvr). At negative Pra values, such as during inspiration, the abdominal veins collapse. This impedes VR and causes a flat line in the curve. Both curves intersect at the normal resting state for the cardiovascular system where VR equals $\mathrm{CO}$, thus giving a specific $\mathrm{CO}$ and Pra. Any change in curve position, as in diseased states, creates a new steady state with a different $\mathrm{CO}$ and Pra. (Adapted from ${ }^{14-16}$ )

and pulmonary capillary wedge pressure) that are associated with specific causes of shock.

5. Determine the value of capnographic and respiratory waveforms in the identification of the mechanism of shock.

6. Describe and integrate the important steps to evaluate the patient in shock before performing bedside ultrasound.
Le système circulatoire et les courbes de fonction cardiaque. A) Le système circulatoire est un circuit fermé comportant des éléments artériels (en rouge) et veineux (en bleu); $70 \%$ du volume sanguin étant dans le système veineux. Il y a trois compartiments: 1) intrathoracique, 2) extrathoracique ou abdominal et 3) péricardique qui inclut le cœur. Le retour veineux (VR) dépend du gradient entre la pression veineuse systémique moyenne (Pms) et la pression de l'oreillette droite (Pra). Il est inversement corrélé à la résistance au retour veineux (Rvr). La Pms est déterminée par la distribution du volume sanguin total entre les veines et les artères et par la compliance veineuse. La Pms est principalement déterminée par le volume contraint (environ $30 \mathrm{~mL} \mathrm{~kg}^{-1}$ ) qui n'est qu'une partie du réservoir veineux. La plus grande partie du volume n'étant pas contrainte. $\mathrm{Pa}=$ pression artérielle; $\mathrm{Ra}=$ artériel résistance $\mathrm{CO}=$ débit cardiaque. B) Dans un circuit fermé, le retour veineux (VR) doit être égal au débit cardiaque (CO) et il peut être décrit avec des courbes de fonction cardiaque (pression-débit). La courbe de la fonction cardiaque (ou courbe de Starling) décrit la relation entre le $\mathrm{CO}$ (variable dépendante) et la pression de l'oreillette droite (Pra) (variable indépendante). Avec l'élévation de la Pra, le $\mathrm{CO}$ augmente de façon proportionnelle jusqu'à atteindre un plateau, lorsque le cœur devient trop distendu. La courbe du VR montre l'association entre le VR (variable dépendante) et la Pra (variable indépendante) mais la relation est inverse; une élévation de la Pra entraîne une diminution du VR. L'endroit où la ligne du VR traverse l'axe des $\mathrm{x}$ correspond à la pression veineuse systémique moyenne (Pms), la pression du système quand le $\mathrm{CO}$ et le VR sont à zéro ou que le cœur est arrêté. La pente de la courbe du VR traduit la résistance au retour veineux (Rvr). Pour des valeurs négatives de la Pra, par exemple au cours de l'inspiration, les veines abdominales se collabent. Cela gêne le VR et crée un plateau dans la courbe. Les deux courbes se croisent à l'état de repos normal du système cardiovasculaire lorsque le VR est égal au CO, donnant ainsi un CO et un Pra spécifiques. Tout changement dans la position de la courbe, comme dans des états pathologiques, crée un nouvel état stable avec un $\mathrm{CO}$ et une Pra différents. (D'après ${ }^{14-16}$ )

\section{Part I: Focus on the clinical approach}

Importance of hemodynamic instability

Hypotension is defined by a low blood pressure and is a common occurrence in patients being managed in the operating room and the intensive care unit (ICU). In a study by Walsh et al. involving 18,989 non-cardiac 


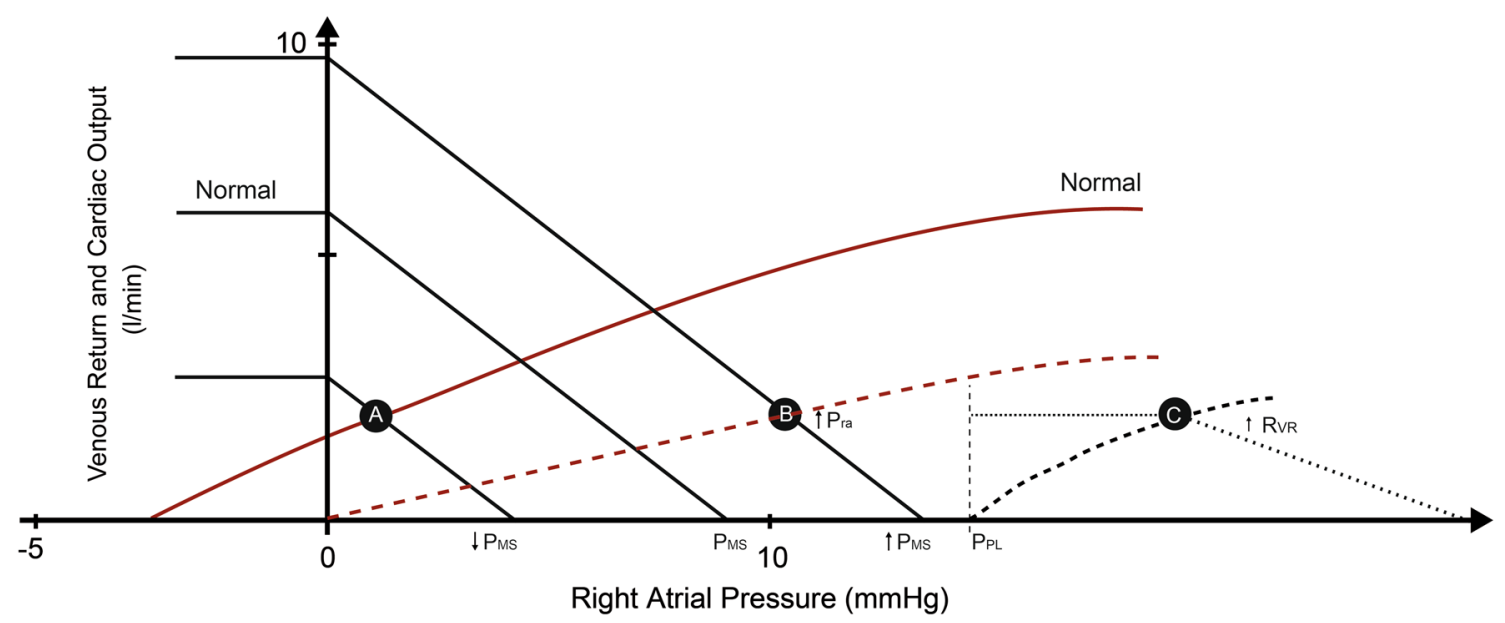

Fig. 2 Mechanism of reduction in venous return. Identical reduction in venous return and cardiac output from three different mechanisms: A) Hemorrhagic shock with reduction in the mean systemic venous pressure (Pms), where the right atrial pressure (Pra) is also reduced, but there is no change in resistance to venous return (Rvr). B) Cardiogenic shock results in an increase in Pra and a compensatory increase in Pms, but no change in Rvr. C) Resistive shock, such as pneumothorax, with increased Rvr and a compensatory increase in the Pms and in the Pra resulting from an increase in pleural pressure $(\mathrm{Ppl})$

surgical patients, a mean arterial pressure below $55 \mathrm{mmHg}$ occurred intraoperatively for at least five minutes in $43 \%$ of patients, and it lasted for more than $20 \mathrm{~min}$ in $10.4 \%$ of their cohort. ${ }^{1}$ Hemodynamic instability is the presence of persistent hypotension and may result in a shock state. Shock is defined as a condition where oxygen transport is inadequate to meet the body's oxygen demand. Hypotension may not always cause hypoperfusion or a shock state, though several studies have shown its association with ischemic stroke, ${ }^{2}$ myocardial injury, ${ }^{1}$ renal failure, ${ }^{3}$ and increased mortality in non-cardiac surgery. ${ }^{4}$ In the context of cardiac surgery, hemodynamic instability is manifested by difficulty separating from cardiopulmonary bypass or low cardiac output (CO) syndrome, though hypotension is most often due to vasodilatation. The presence of low $\mathrm{CO}$ syndrome is associated with significant postoperative morbidity and mortality. ${ }^{5,6}$

Prolonged hemodynamic instability may be more dangerous than a short episode of hypotension, particularly in the elderly. ${ }^{7}$ The duration of shock is a major determinant of survival in trauma, ${ }^{8}$ septic shock, ${ }^{9}$ myocardial infarction, ${ }^{10}$ and stroke. ${ }^{11}$ This has led to the term "golden hour", which implies that prolonged shock of more than one hour can harm individual organs and result in death. It is important that clinicians managing the hemodynamically unstable patient rapidly identify the mechanism(s) of shock so that the most appropriate
Mécanisme de réduction du retour veineux. Réductions identiques du retour veineux et du débit cardiaque selon trois mécanismes différents: A) Choc hémorragique avec baisse de la pression veineuse systémique moyenne (Pms) où la pression de l'oreillette droite (Pra) est également réduite, mais sans modification de la résistance au retour veineux (Rvr). B) Le choc cardiogénique a pour conséquence une augmentation de la Pra et une augmentation compensatrice de la Pms, mais sans modification de la Rvr. C) Choc résistif, tel qu'un pneumothorax avec Rvr augmentée et augmentation compensatrice de la Pms et de la Pra résultant d'une augmentation de la pression pleurale $(\mathrm{Ppl})$

treatment can be initiated without delay. Once the basic initial steps are undertaken in any patient with shock, bedside echocardiography should be considered as soon as possible in order to clarify the diagnosis and facilitate treatment. ${ }^{12}$

In this series of two continuing professional development (CPD) modules, we propose a diagnostic and therapeutic approach to help manage hemodynamically unstable patients. In the first CPD module, we present the basic pathophysiological principles of the mechanism of shock. In addition, we review some of the clinical signs and monitoring clues that can direct the clinician toward a specific diagnosis. In the second CPD module, we will concentrate on the integration of bedside cardiac, pulmonary, abdominal, and vascular ultrasound in order to identify the mechanism and underlying etiology of shock.

\section{Pathophysiological approach to shock}

In order to help identify the mechanism of shock, we combine three complementary elements: A) the concept of venous return (VR); B) the ventricular pressure-volume relationship; and C) the use of bedside ultrasound. ${ }^{13}$ Hemodynamic assessment of shock often begins with the determination of $\mathrm{CO}$, heart rate and rhythm, preload, afterload, and contractility. The $\mathrm{CO}$ represents the blood pumped from the heart, which in a closed cardiovascular system must equal the VR to the heart. The concept of VR 


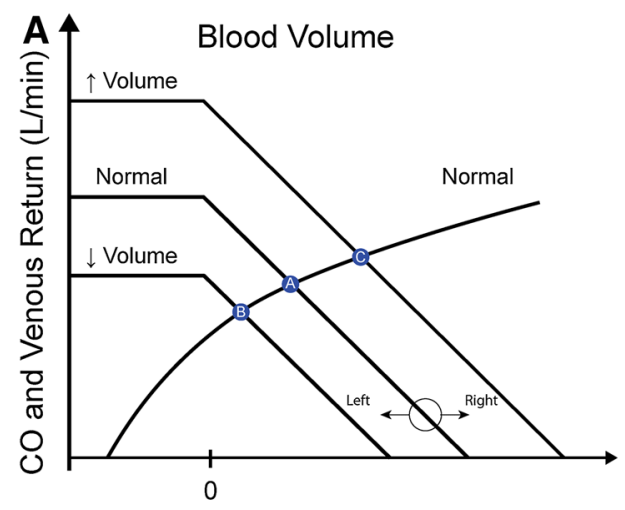

Right Atrial Pressure $(\mathrm{mmHg})$

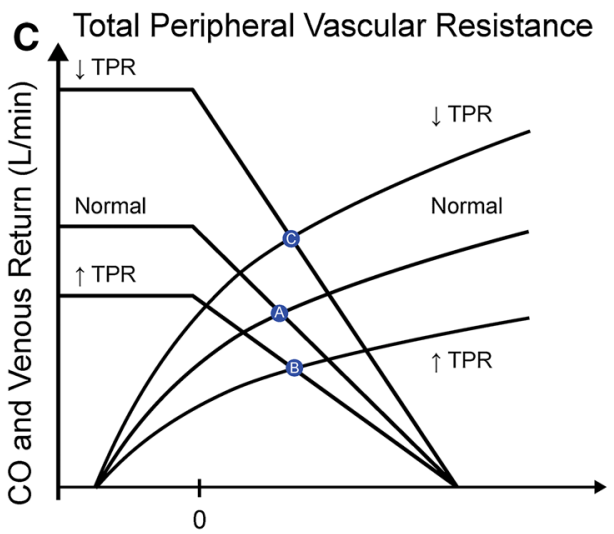

Right Atrial Pressure $(\mathrm{mmHg})$

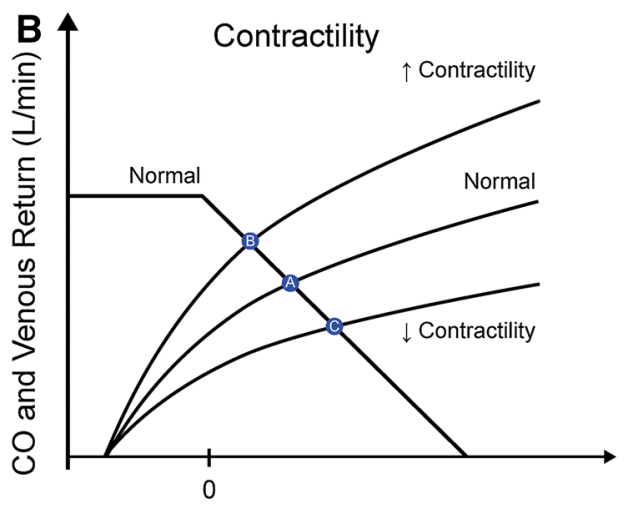

Right Atrial Pressure (mmHg)

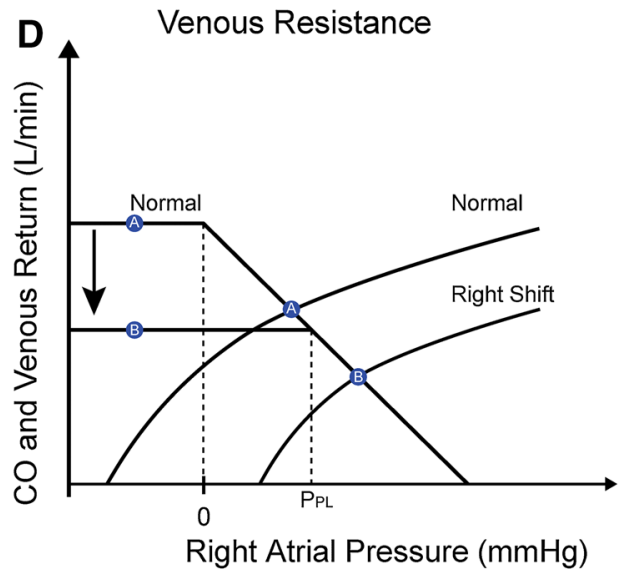

is increased, and/or 3) there is increased resistance to venous return. The relationship between VR and $\mathrm{CO}$ can be shown in a simple graph (Fig. 1B). Figure 2 illustrates how similar reductions in VR and, consequently, CO from three different mechanisms will alter this graph.

The systemic venous pressure depends on volume status and the compliance of the venous reservoir. Thus, it can be reduced by both hemorrhagic shock and distributive shock. The VR curve in hemorrhagic shock is altered to show less VR (leftward shift with an unchanged slope), reduced $\mathrm{CO}$ (unchanged Starling slope) and reduced right atrial pressure (Figs. 2 and 3A).

In cardiogenic shock, right atrial pressure is elevated. Cardiogenic shock can result from left ventricular and right ventricular systolic dysfunction, diastolic failure, left and right ventricular outflow tract obstruction, ${ }^{17,18}$ acute valvular insufficiency, and pulmonary embolism. Hypoxemia and hypercapnia, if acute and uncorrected, will cause pulmonary hypertension, leading to increased right atrial pressure, and if untreated in susceptible patients, will produce right heart failure. The VR curve with systolic dysfunction or reduced contractility shows a reduced VR (rightward shift of VR curve), reduced CO (reduced Starling slope), increased right atrial pressure (Fig. 2) and 
4 Fig. 3 Determinants of venous return. A) Changes in blood volume or venous compliance alter the venous return (VR) curve. In hemorrhagic shock, the stressed blood volume decreases. This reduces the mean systemic venous pressure (Pms), which shifts the VR curve to the left. At the new steady state, both cardiac output (CO) and right atrial pressure (Pra) are decreased (point B). An increase in stress volume will lead to more circulating blood. This is the result of more blood generating an increased transmural pressure on the venous side, leading to an increase in Pms and Pra and, ultimately, an increase in CO. Therefore, an increase in blood volume raises the stressed volume, increasing Pms and shifting the VR curve to the right. At the new steady state, both the $\mathrm{CO}$ and Pra are increased (point C). B) Changes in inotropy affect the cardiac function curve but not the VR curve. In cardiogenic shock, the cardiac function curve shifts downwards so CO is decreased and right atrial pressure (Pra) is increased as less blood is ejected with each beat (point C). As compensation, the mean systemic venous pressure increases, shifting the VR curve to the right without changing its slope (not shown). A positive inotropic effect shifts the cardiac function curve upwards so $\mathrm{CO}$ is increased and Pra is decreased as more blood is ejected from the heart (point B). C) Changes in total peripheral resistance (TPR) or afterload alter systemic arterial pressure and venous return (VR) to the heart, affecting both curves. The right atrial pressure changes with TPR are balanced. This results in a rotation of the VR curve. A decrease in TPR (afterload) decreases arterial pressure, which increases CO (upward shift of cardiac function curve) and VR (clockwise rotation of VR curve) (point C). An increased TPR (afterload) increases arterial pressure, which reduces CO (downward shift of cardiac function curve) and returns less blood to the heart (counterclockwise rotation of the VR curve) (point B). D) In the presence of increased venous resistance, the VR is determined by the difference between the mean systemic venous pressure and the increased external pressure (pleural, pericardial, or abdominal) (point B), not the right atrial pressure. The inflection of the plateau point on the VR curve is then shifted downward. The cardiac function curve is shifted to the right as cardiac function is impaired. To maintain VR, the mean systemic venous pressure must increase significantly (not shown). $\mathrm{CO}=$ cardiac output, $\mathrm{Ppl}=$ pleural pressure

a compensatory increase in mean systemic venous pressure. Increasing contractility with inotropes will increase VR by reducing right atrial pressure (Fig. 3B). The effect of changing afterload or total peripheral resistance on VR and CO is shown in Fig. 3C.

The best example of an acute increase in resistance to VR is hypotension from compression of the inferior vena cava (IVC) in a pregnant patient. Other examples include acute abdominal compartment syndrome, as well as tamponade, pneumothorax, and severe hyperinflation with intrinsic positive end-expiratory pressure (PEEP), though the later three examples also exert their effect via increasing Pra. An increase in resistance to VR causes shock by preventing blood from reaching the heart despite the presence of normal blood volume and cardiac function. Increased resistance to
Déterminants du retour veineux. A) Les modifications du volume sanguin ou de la compliance veineuse altèrent la courbe de retour veineux (VR). Au cours du choc hémorragique, le volume sanguin contraint diminue. Cela diminue la pression veineuse systémique moyenne (Pms), ce qui déplace la courbe de VR vers la gauche. Dans le nouvel état stable, le débit cardiaque (CO) et la pression de l'oreillette droite (Pra) sont tous deux abaissés (point B). Une augmentation du volume contraint entraînera la mise en circulation de plus de sang dans le compartiment artériel. En effet, plus de sang entraîne une augmentation de la pression transmurale du côté veineux, aboutissant à une augmentation de la Pms et de la Pra et, au bout du compte, à une augmentation du CO. En conséquence, une augmentation du volume sanguin élève le volume contraint, augmentant la Pms et déplaçant la courbe de VR vers la droite. Au nouvel état stable, le CO et la Pra sont tous deux augmentés (point C). B) Des modifications de l'inotropisme affectent la courbe de la fonction cardiaque, mais pas la courbe du retour veineux (VR). Au cours du choc cardiogénique, la courbe de la fonction cardiaque se déplace vers le bas, si bien que le débit cardiaque (CO) est diminué et que la pression de l'oreillette droite (Pra) est augmentée puisque moins de sang est éjecté à chaque battement (point C). Pour compenser, la pression veineuse systémique moyenne augmente, déplaçant la courbe du VR vers la droite, sans en modifier la pente (non illustré). Un effet inotrope positif déplace la courbe de la fonction cardiaque vers le haut, si bien que le CO est augmenté et que la Pra est diminuée puisque plus de sang est éjecté par le cœur (point B). C) Des modifications de la résistance périphérique totale (TPR) ou de la postcharge altèrent la pression artérielle systémique et le retour veineux (VR) vers le cœur, affectant les deux courbes. Les modifications de la pression de l'oreillette droite avec la TPR sont équilibrées. Cela entraine une rotation de la courbe du VR. Une diminution de la TPR (postcharge) abaisse la pression artérielle, ce qui augmente le débit cardiaque (CO) (déplacement vers le haut de la courbe de la fonction cardiaque) et le VR (rotation dans le sens horaire de la courbe du VR) (point C). Une TPR (postcharge) augmentée élève la pression artérielle, ce qui abaisse le $\mathrm{CO}$ (déplacement vers le bas de la courbe de la fonction cardiaque) et renvoie moins de sang vers le cœur (rotation dans le sens antihoraire de la courbe du VR) (point B). D) En présence d'une augmentation de la résistance veineuse, le retour veineux (VR) est déterminé par la différence entre la pression veineuse systémique moyenne et la pression externe augmentée (pleurale, péricardique ou abdominale) (point B), et non par la pression de l'oreillette droite. Le point d'inflexion du plateau sur la courbe du VR est alors déplacé vers le bas. La courbe de la fonction cardiaque est déplacée vers la droite car la fonction cardiaque est altérée. Pour maintenir le VR, la pression veineuse systémique moyenne doit augmenter de façon significative (non illustré). $\mathrm{CO}=$ débit cardiaque, $\mathrm{Ppl}=$ pression pleurale

VR (Fig. 2) will reduce VR (modified VR slope), reduce CO (reduced Starling slope), increase right atrial pressure and increase Pms. The increased pleural pressure, for instance, with a pneumothorax becomes the limiting factor to VR (Fig. 3D). This can explain why relief of a pneumothorax or tamponade can significantly increase $\mathrm{CO}$ in some patients; specifically, once the significant elevation in Pra seen in these conditions is corrected, the resulting large gradient between Pms and Pra will abruptly increase VR. As a consequence, some patients may develop acute right ventricular failure and pulmonary edema from acute exacerbation of left ventricular diastolic dysfunction following treatment of these conditions. This mechanism also partly explains the so-called re-expansion pulmonary edema. 
Table 1 Shock classification using the concept of venous return

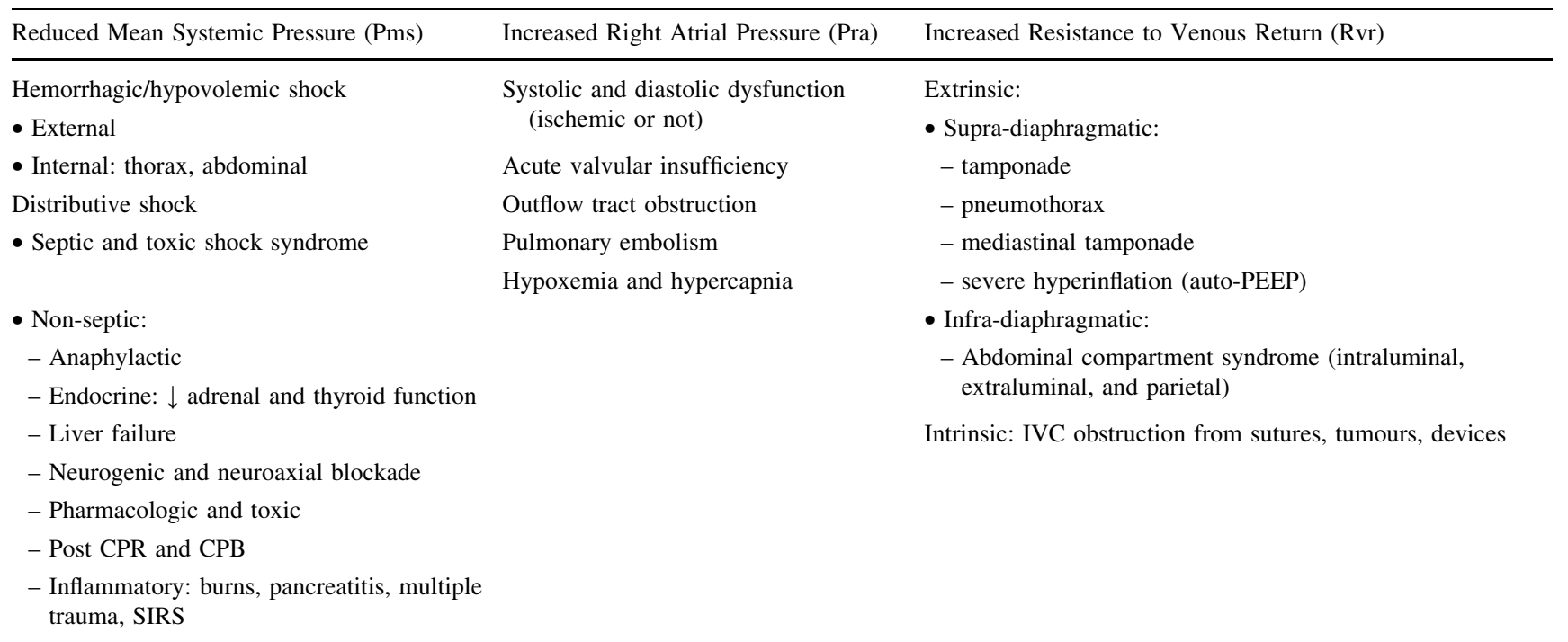

$\mathrm{CPR}=$ cardiopulmonary resuscitation $\mathrm{CPB}=$ cardiopulmonary bypass; $\mathrm{IVC}=$ inferior vena cava; $\mathrm{PEEP}=$ positive end-expiratory pressure; SIRS $=$ systemic inflammatory response syndrome

There are situations, however, where more than one component of the VR curve is modified. For example, some inotropic agents not only change contractility (which also results in a lowering of Pra) but also reduce resistance to VR through peripheral vasodilatation; however, if the patient is hypovolemic, reduced Pms can also occur. ${ }^{15}$ In addition, pulmonary conditions such as pneumothorax can compress the heart (like a tamponade), while associated hypoxemia can lead to pulmonary hypertension and an increased Pra. Table 1 summarizes the most common causes of shock using the concept of VR.

\section{Ventricular pressure-volume relationship}

The relationship between ventricular function and hemodynamics is best described using pressure-volume loops. These curves show a graphic description of ventricular function by displaying the volume of a single cardiac cycle against pressure over time (Fig. 4A). This is characterized by seven time-related events. Though the pressure-volume loop can be obtained through continuous pressure and volume measurement, this is rarely done in clinical practice. Individual determinants of the pressurevolume loop may be obtained by using 1) echocardiography to assess the volume of cardiac chambers, 2) a pulmonary artery catheter (PAC) to estimate filling pressures, and 3) an arterial pressure catheter to measure systemic pressures (Fig. 4B).

\section{Inferior vena cava assessment}

Finally, bedside echocardiography is useful at two levels. First, it can rapidly identify the mechanism of shock, and second, it can also identify the underlying etiology. The quickest method to stratify the mechanism of shock is through examination of the IVC. There are limitations to using the IVC to estimate mean systemic venous pressure, which will be discussed in the second CPD module of this two-part series on bedside clinical and ultrasound-based approaches to hemodynamic instability.

Figure 5 summarizes the stratification of shock by integrating an ultrasound examination of the IVC, the pressure-volume loop, and the concept of VR. The mechanism of shock from an increase in the resistance to VR is more complex, and specific examples will be given in the second CPD module. Other non-echocardiographic signs of reduced Pms, hypovolemia, or fluid responsiveness have recently been reviewed. ${ }^{19}$

\section{Practical approach to shock before using bedside ultrasound}

An approach to hemodynamically unstable patients is proposed in Fig. 6. Table 2 summarizes some key elements that can be used to assess the mechanism of shock.

\section{History, physical examination, and basic laboratory tests}

The patient's history may offer crucial information that may be indispensible in managing their hemodynamic instability. Unfortunately, an adequate history cannot always be obtained from an unstable patient; hence, information must be retrieved from other sources, including the patient's family or friends. Reviewing the medical record is recommended, but this is difficult to do while performing resuscitation. Particular attention should be given to drug usage, which can complicate resuscitation. 

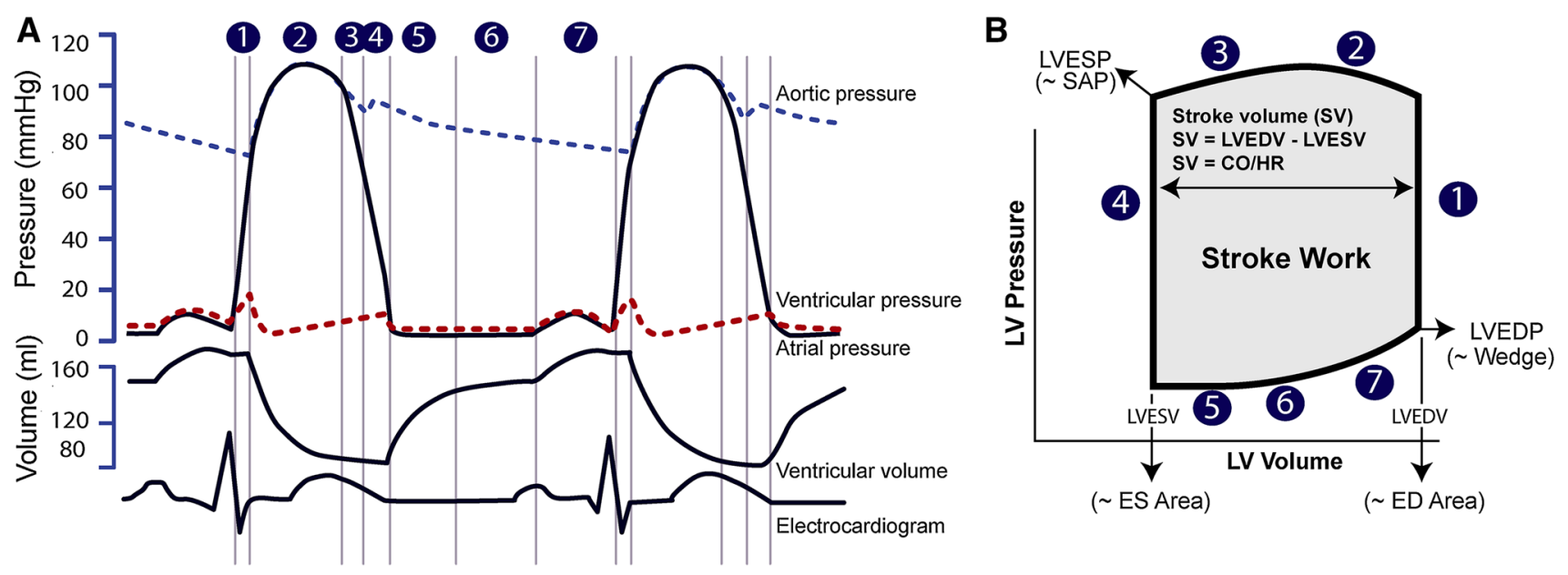

Fig. 4 Pressure and volume during a cardiac cycle. A) Changes in aortic, atrial, and ventricular pressures and ventricular volume are presented in relation to the electrocardiogram. Left ventricular pressure and volume over time during a cardiac cycle is characterized by seven time-related events. Isovolumic contraction (1) is followed by early (2) and late (3) ejection. Diastole starts with isovolumic relaxation (4), followed by the early filling phase after the opening of the mitral valve (5), diastasis (6), and atrial contraction (7). B) The corresponding left ventricular (LV) pressure-volume relationship during one cardiac cycle is shown. The LV end-systolic pressure (LVESP) can be estimated using systolic arterial pressure (SAP), and the LV end-diastolic pressure (LVEDP) can be estimated with the pulmonary artery-derived "wedge" pressure at end diastole. On the x-axis, the LV end-systolic volume (LVESV) can be estimated with the end-systolic (ES) area, and the LV end-diastolic volume (LVEDV) can be estimated with the end-diastolic (ED) area using echocardiography. The stroke volume (SV), which is the difference between the LVEDV and the LVESV, can be calculated from the ratio of the cardiac output (CO) (obtained by Doppler or thermodilution) divided by the heart rate (HR). The LV stroke work corresponds to the area of the LV pressure-volume diagram (gray area). Changes in LV compliance can explain why filling pressure does not always correlate with ventricular size. (Adapted with permission from ${ }^{34}$ )

A brief physical examination of the patient must be carried out without delay in order to document the clinical signs of shock, evaluate neurological status, examine the cardiopulmonary system, assess abdominal compliance, and inspect the extremities. Clinical observation of unequal pupils, skin rashes, cirrhosis stigmata, bruising of the flanks (Grey Turner's sign), or leg edema can help to narrow the diagnosis.

Screening laboratory tests, such as a complete blood count, electrolytes, glucose, troponin, and blood gases, can provide valuable information. Nevertheless, these test results are rarely immediately available unless point-ofcare laboratory testing is used. Procalcitonin levels are being used more frequently in emergency rooms and in the ICU in order to rule out bacterial infection and adjust antibiotics. $^{20}$
Pression et volume au cours d'un cycle cardiaque. A) Une modification des pressions aortique, auriculaire et ventriculaire, et du volume ventriculaire sont présentées en relation avec l'électrocardiogramme. La pression et le volume ventriculaires gauches au cours d'un cycle cardiaque sont caractérisés par sept événements consécutifs. La contraction isovolumétrique (1) est suivie de la phase d'éjection précoce (2) et tardive (3). La diastole commence par la relaxation isovolumétrique (4), suivie d'une phase de remplissage précoce après l'ouverture de la valve mitrale (5), la diastase (6) et de la contraction auriculaire (7). B) L'évolution de la relation pression-volume du ventricule gauche (LV) correspontant à ces événements pendant un cycle cardiaque est présentée. La pression télésystolique du LV (LVESP) peut être estimée à l'aide de la pression artérielle systolique (SAP) alors que la pression télédiastolique du LV (LVEDP) peut être estimée avec la pression capillaire pulmonaire bloquée en fin de diastole. Sur l'axe des x, le volume télésystolique du LV (LVESV) peut être estimé avec la surface de fin de systole (ES), et le volume télédiastolique du LV (LVEDV) peut être estimé à l'aide de la surface de fin de diastole (ED) mesurée par échocardiographie. Le volume d'éjection systolique (SV), qui est la différence entre le LVEDV et le LVESV, peut être calculé à partir de la mesure du débit cardiaque (CO) (obtenu par Doppler ou thermodilution) divisé par la fréquence cardiaque (HR). Le travail systolique ou d'éjection du LV correspond à la surface du graphique pression-volume du LV (zone grise). Des modifications de la compliance du LV peuvent expliquer pourquoi la pression de remplissage n'est pas toujours corrélée à la taille du ventricule. (Adapté avec permission $\mathrm{de}^{34}$ )

\section{Monitoring devices}

Careful examination of the continuous numerical and waveform variables displayed on the monitor can also point to the mechanism of shock. Commonly displayed variables are the electrocardiography (ECG), pulse oximetry, capnography or end-tidal carbon dioxide $\left(\mathrm{ETCO}_{2}\right)$, mean arterial pressure, and the ventilator variables (including airway pressure, volume, and flow). In some patients, central venous pressure (CVP) or right atrial pressure, pulmonary artery pressure, right ventricular pressure, ${ }^{21}$ and brain or somatic near-infrared spectroscopy (NIRS) can be monitored.

Interpretation of the rate and rhythm of the ECG with ST analysis is the basis of advanced cardiac and life support. In addition, specific ECG findings may include 


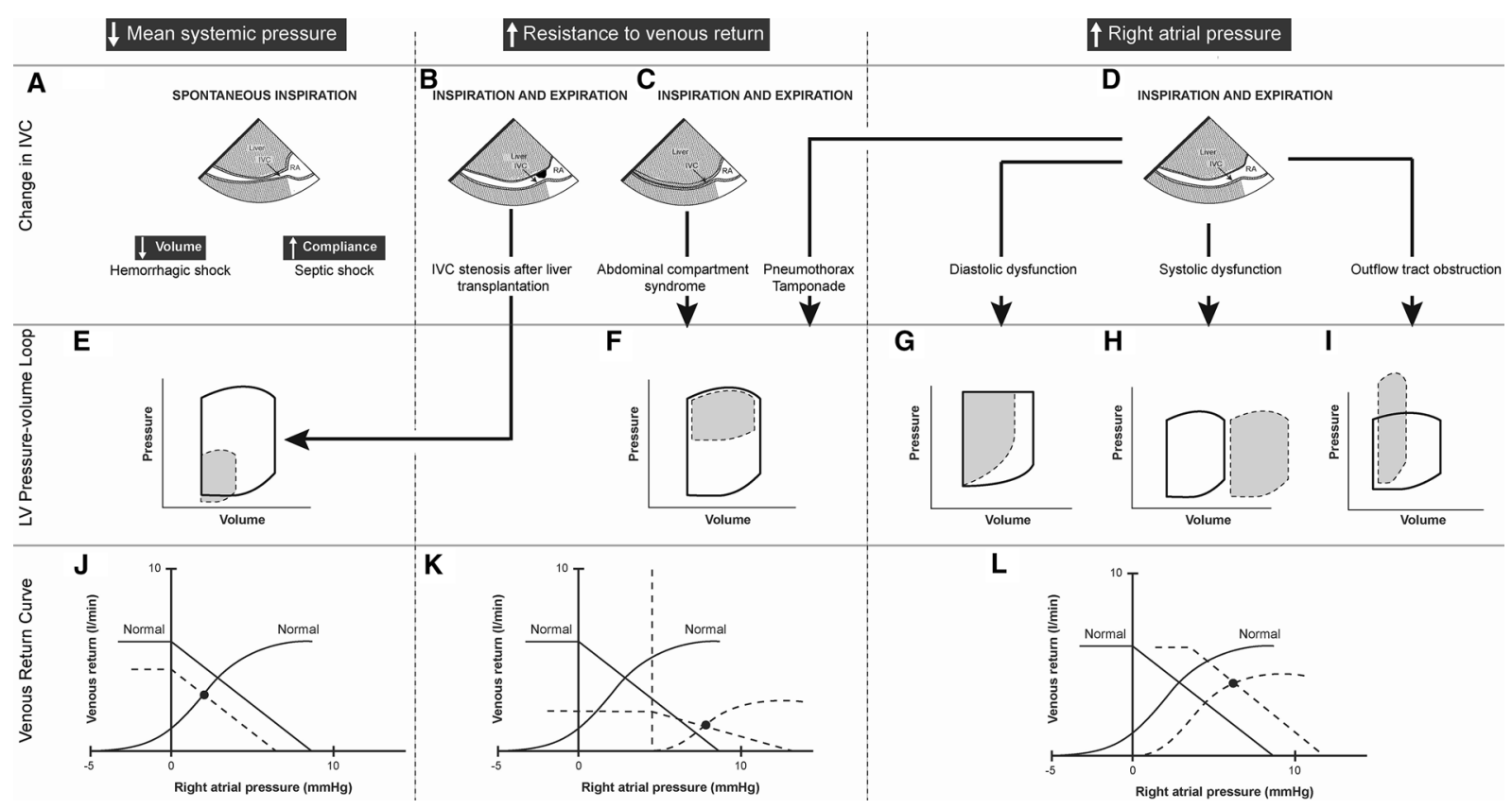

Fig. 5 Mechanism of hemodynamic instability. Classification of shock state using the inferior vena cava (IVC) examination, the left ventricular (LV) pressure-volume (PV) loop estimation, and the concept of venous return (VR).In patients with low mean systemic venous pressure, the IVC will be small (5A), with respiratory variation in a spontaneously breathing patient, reduced ventricular pressure and volume in the PV loop $(5 \mathrm{E})$, and medial shift of the VR curve (5J). The IVC can be small, normal, or dilated in the presence of increased resistance to VR. In the setting of IVC obstruction near the right atrium, the distended IVC does not vary with ventilation (5B); however, the PV loop (5E) and the VR curve (5J) will behave as if the patient has reduced mean systemic venous pressure. These patients are typically unresponsive to fluid administration. If fluid is given, splanchnic venous congestion may occur, causing elevated liver enzymes, increasing lactate level and deterioration in renal function. In the setting of abdominal compartment syndrome, the IVC diameter is significantly reduced, also without respiratory variation (5C). The elevated intra-abdominal pressure is transmitted to the pleural pressure; the PV loop has a normal or reduced stroke volume but increased ventricular pressure $(5 \mathrm{~F})$. This is similar to diastolic dysfunction, except that no intrinsic myocardial dysfunction is present. Tamponade and pneumothorax usually distend the IVC (5D), and the increased external pressure (vertical dotted line in $5 \mathrm{~K}$ ) displaces the PV loop upward $(5 \mathrm{~F})$ with a normal or reduced stroke volume and reduces the VR curve slope $(5 \mathrm{~K})$. An increase in right atrial pressure distends the IVC (5D) without any respiratory variation. The PV loop will depend on the mechanism of cardiogenic shock. In diastolic dysfunction (5G), a leftward shift of the PV loop is seen with increased LV pressure but with normal or reduced volume. Systolic dysfunction shows a rightward shift of the PV loop $(5 \mathrm{H})$ as the major characteristic of $\mathrm{LV}$ or right ventricular (RV) systolic dysfunction is chamber dilatation. If either LV or RV outflow tract obstruction is present, $\mathrm{LV}$ or RV volume is reduced, but the intraventricular pressure is increased (5I). In all three cases, the VR curve is displaced to the right $(5 \mathrm{~L})$. (Adapted from ${ }^{13}$ )
Mécanisme de l'instabilité hémodynamique. Classification du choc à l'aide de l'examen de la veine cave inférieure (IVC), de l'évaluation de la boucle pression-volume (PV) du ventricule gauche (LV) et du concept de retour veineux (VR). Chez les patients ayant une pression veineuse systémique moyenne basse, l'IVC sera petite (5A) et variera durant la respiration spontanée, la boucle $\mathrm{PV}$ montrera une pression et un volume ventriculaire réduits (5E), le tout assorti d'un déplacement vers la gauche de la courbe du VR (5J). L'IVC peut être petite, normale ou dilatée en présence d'une résistance accrue au VR. Dans le cas d'une obstruction de l'IVC à proximité de l'oreillette droite, l'IVC distendue ne varie pas avec la respiration (5B); toutefois, la boucle PV (5E) et la courbe de VR (5J) se comporteront comme si le patient avait une pression veineuse systémique moyenne abaissée. Ces patients ne répondent habituellement pas à l'administration de liquides, laquelle peut alors provoquer une congestion veineuse splanchnique assortie d'une élévation des enzymes hépatiques et du lactate, ainsi qu'une détérioration de la fonction rénale. Dans le cadre d'un syndrome du compartiment abdominal, le diamètre de l'IVC est significativement réduit, également sans variation respiratoire (5C). La pression intra-abdominale élevée est transmise à la pression pleurale; la boucle PV montre un volume d'éjection normal ou abaissé, mais une pression ventriculaire augmentée $(5 \mathrm{~F})$. Cela est semblable à une dysfonction diastolique, à la différence qu'il n'existe pas ici de dysfonction myocardique intrinsèque. Une tamponnade et un pneumothorax distendent habituellement l'IVC (5D) et la pression externe augmentée (ligne pointillée verticale dans $5 \mathrm{~K}$ ) déplace la boucle PV vers le haut $(5 \mathrm{~F})$ avec un volume d'éjection systolique normal ou réduit et diminue la pente de la courbe du VR $(5 \mathrm{~K})$. Une augmentation de la pression de l'oreillette droite distend l'IVC (5D) sans aucune variation respiratoire. La boucle PV sera tributaire du mécanisme du choc cardiogénique. Avec une dysfonction diastolique (5G), on observe un déplacement vers la gauche de la boucle PV avec une pression augmentée du LV, mais un volume normal ou réduit. $\mathrm{La}$ dysfonction systolique provoque un déplacement vers la droite de la boucle PV $(5 \mathrm{H})$, la caractéristique principale d'une dysfonction systolique du LV ou du ventricule droit (RV) étant la dilatation ventriculaire. Dans le cas d'une obstruction de la chambre de chasse du LV ou du RV, le volume du LV ou du RV est réduit mais la pression intraventriculaire est augmentée (5I) et la courbe de VR est déplacée vers la droite $(5 \mathrm{~L})$. (D'après ${ }^{13}$ ) 


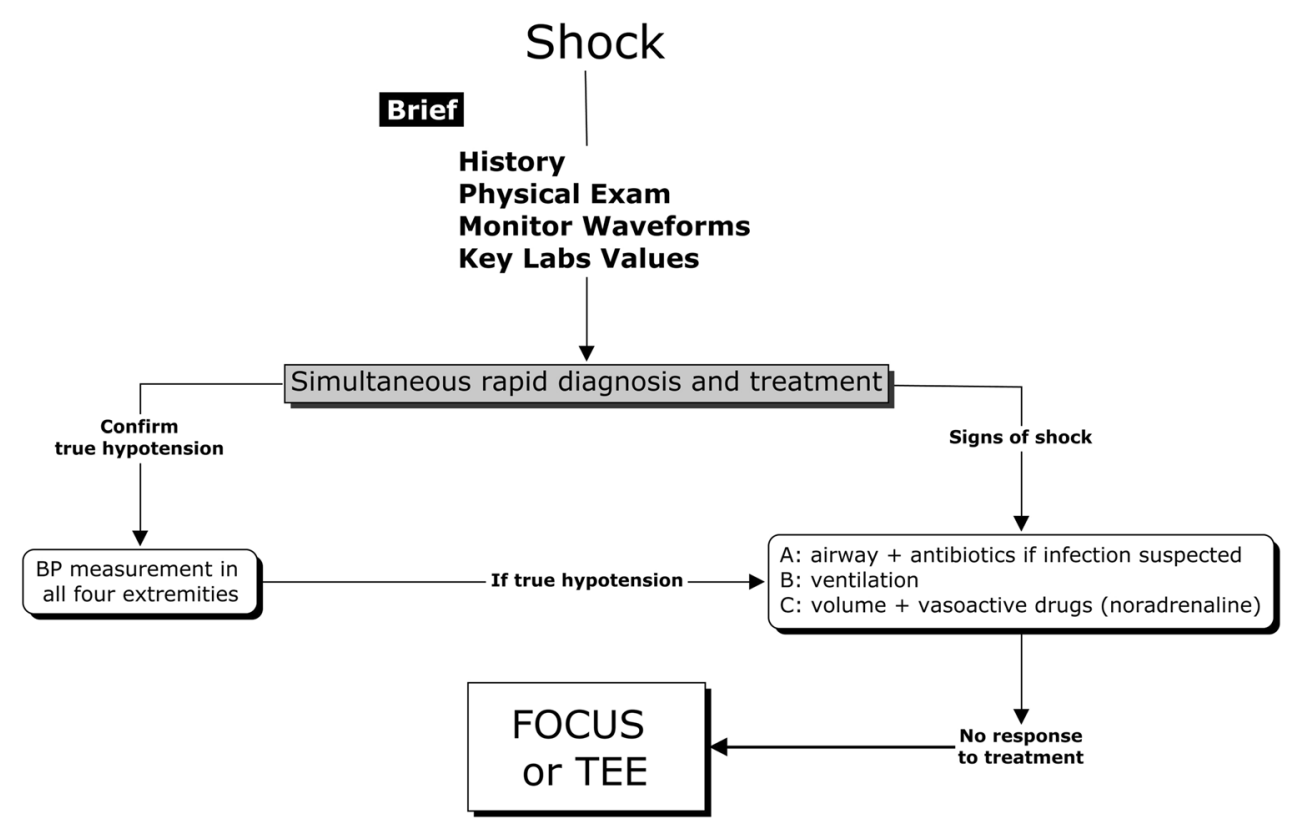

Fig. 6 General approach to shock. In the presence of shock, a brief focused history is obtained and an examination of both the patient, the monitor values and the waveforms is performed. In addition, key laboratory values are obtained. An important part of the clinical evaluation is to make sure that true hypotension is present, and we recommend obtaining blood pressure from all four extremities in order to exclude patients with pseudo-hypotension (e.g., from vascular disease). Once hypotension is confirmed and the signs of shock are present, an $\mathrm{ABC}$ approach is proposed. The $A$ stands for airway management, but also antibiotics, because survival in septic shock depends on rapid administration of antibiotics. The $B$ stands for breathing or ventilation because hypercapnea, in susceptible patients, can lead to pulmonary hypertension, increased right atrial pressure, and reduced venous return. The $C$ stands for circulatory support. Volume administration should be rapidly considered because shock with reduced mean systemic venous pressure is the most common type of shock. Noradrenaline should be the first vasoactive agent used. If these initial steps fail, a bedside surface-focused echographic examination or transesophageal echocardiography (TEE) should be considered

peak $\mathrm{P}$ waves in acute pulmonary embolism, elevated $\mathrm{T}$ waves in brain-heart syndrome, Osborn waves in hypothermia, and microvoltage in tamponade (Fig. 7). Left ventricular cardiac dysfunction is more commonly associated with the presence of left bundle branch block than with right bundle branch block. ${ }^{22}$

Pulse oximetry is useful in detecting hypoxemia, and the pulsatile waveform display can noninvasively mimic the information obtained from invasive arterial pressure monitoring. ${ }^{19}$ Respiratory variations of the amplitude of the pulse oximetry signal may indicate reduced Pms. ${ }^{23}$ Following a fluid challenge, a decrease in respiratory variation of the waveform may confirm fluid
Approche générale de l'état de choc. En présence d'un patient en état de choc, on obtient un résumé de ses antécédents pertinents; le clinicien examine le patient et analyse les tracés tout en consultant les tests de laboratoires importants. Une partie cruciale de l'évaluation clinique consiste à s'assurer qu'il y a une véritable hypotension et nous recommandons de mesurer la pression artérielle aux quatre membres pour exclure les patients qui présenteraient une pseudo-hypotension (par exemple causée par une maladie vasculaire). Une fois l'hypotension confirmée et les signes de choc reconnus, une approche selon un protocole « $\mathrm{ABC}$ » est proposée. Le $A$ (airway management) représente la gestion des voies aériennes, mais aussi les antibiotiques car la survie en cas de choc septique dépend de l'administration rapide d'antibiotiques. Le $B$ (breathing) représente la ventilation ou la respiration parce qu'une hypercapnie chez des patients à risque peut conduire à une hypertension pulmonaire, une augmentation de la pression de l'oreillette droite et un retour veineux réduit. Le $C$ (circulation) représente le soutien circulatoire. Une réplétion volémique doit être rapidement envisagée parce qu'un choc avec baisse de la pression veineuse systémique moyenne est le type de choc le plus fréquent. La noradrénaline doit être utilisée comme premier agent vasoactif. Si ces étapes initiales échouent, un examen échographique de surface au chevet du patient ou une échocardiographie transœsophagienne (TEE) doit être envisagé

responsiveness; however, if the respiratory variations increase, right ventricular dysfunction should be suspected.

The arterial pressure waveform can have certain characteristics that will suggest a specific shock mechanism. These include pulsus alternans (left ventricular failure), pulsus paradoxus (tamponade, hypovolemia, and chronic obstructive pulmonary disease [COPD] exacerbation) ${ }^{24}$ pulsus tardus (aortic stenosis and left ventricular failure), pulsus bisferiens and the Brockenbrough-Braunwald phenomenon, which are pathognomonic for left ventricular outflow tract obstruction $^{18}$ (Fig. 8). The arterial pressure waveform can be analyzed alone, though the combination with other 
Table 2 Key elements in assessment of an hemodynamically unstable patient

\begin{tabular}{|c|c|c|c|}
\hline & Reduced Mean Systemic Venous Pressure (Pms) & $\begin{array}{l}\text { Increased Right Atrial Pressure } \\
\text { (Pra) }\end{array}$ & $\begin{array}{l}\text { Increased Resistance to Venous } \\
\text { Return (Rvr) }\end{array}$ \\
\hline History & $\begin{array}{l}\text { Drugs (antihypertensive agents, steroids, antibiotics, } \\
\text { anticoagulants) } \\
\text { Comorbidities (cirrhosis) } \\
\text { Past and recent medical history (abdominal or thoracic } \\
\text { procedures), } \\
\text { Neuraxial blockade }\end{array}$ & $\begin{array}{l}\text { Drugs (Anti-arrhythmic; Beta } \\
\quad \text { blockers) } \\
\text { Coronary artery disease } \\
\text { Hypertension } \\
\text { Acute stroke } \\
\text { Prolonged immobilization } \\
\text { Thrombophilia }\end{array}$ & $\begin{array}{l}\text { Recent abdominal procedure } \\
\text { Central venous access } \\
\text { Surgery involving the IVC }\end{array}$ \\
\hline Exam & $\begin{array}{l}\text { Warm skin temperature } \\
\text { Grey Turner's sign or flank bruising } \\
\text { Cirrhosis stigmatas } \\
\text { Bronchial breath sound }\end{array}$ & $\begin{array}{l}\text { Cold skin temperature } \\
\text { Focal or global neurologic } \\
\quad \text { deficits } \\
\text { Clubbing } \\
\text { Heart murmur }\end{array}$ & $\begin{array}{l}\text { Cold skin temperature } \\
\text { Tense abdomen } \\
\text { Distant cardiac sounds } \\
\text { Unilateral reduction in breath sound }\end{array}$ \\
\hline $\begin{array}{l}\text { Complementary } \\
\text { tests }\end{array}$ & $\begin{array}{l}\text { CBC } \\
\text { Potassium, glucose } \\
\text { Blood culture } \\
\text { Coagulation profile } \\
\text { Amylase } \\
\text { Procalcitonin }\end{array}$ & $\begin{array}{l}\text { CK, troponin } \\
\text { 12-lead ECG }\end{array}$ & $\begin{array}{l}\text { CXR and abdominal films } \\
\text { Arterial blood gas }\end{array}$ \\
\hline
\end{tabular}

Other useful global indicators of shock severity: vital signs, creatinine, liver enzymes, lactate, mixed venous saturation, veno-arterial partial pressure of carbon dioxide $\left(\mathrm{PCO}_{2}\right) . \mathrm{CBC}=$ complete blood count, $\mathrm{CK}=$ creatinine kinase, $\mathrm{CXR}=$ chest radiograph, $\mathrm{ECG}=$ electrocardiogram, $\mathrm{IVC}=$ inferior vena cava

modalities, such as the ECG, may improve diagnostic accuracy in conditions such as left ventricular failure (Fig. 8E). The importance of obtaining reliable and valid blood pressure measurements should be emphasized.

The use of capnography and waveform analysis of $\mathrm{ETCO}_{2}$ has been extensively reviewed. ${ }^{25}$ In patients with shock, capnography may act as a noninvasive $\mathrm{CO}$ monitor. Thus, dynamic interventions such as leg-raising can determine fluid responsiveness. If a patient is fluid responsive, leg raising will typically increase the $\mathrm{ETCO}_{2}$ by $2 \mathrm{mmHg}$ or more. ${ }^{19}$ Certain aspects of the waveform are important to identify, particularly the phase III upslope during COPD exacerbation with the risk of intrinsic PEEP or auto-PEEP, and the downslope which indicates gas losses (i.e. from a bronchopleural fistula). Finally, acute hypotension with the sudden increase in $\mathrm{ETCO}_{2}$ during laparoscopy or saphenoscopy is pathognomonic of carbon dioxide embolism, which can lead to acute right ventricular failure.

Respiratory pressure, flow, and volume waveforms are useful to differentiate if increased airway pressure, whether or not associated with hypotension, results from increased airway resistance or from reduced lung compliance. The volume-pressure diagram is an easy way to distinguish between these two conditions (Fig. 9). In the presence of a pneumothorax or abdominal compartment syndrome, lung compliance is reduced, with a reduced area of the volumepressure diagram and a shortened expiratory flow time.
With increased airway resistance related to auto-PEEP or bronchospasm, the area of the volume-pressure diagram is increased and the expiratory flow time is prolonged. Combining these waveforms with capnography is a much faster method to establish a diagnosis. In both situations, resistance to VR will increase; however, the treatment of the underlying problem is completely different.

In some patients, CVP will be obtained with or without insertion of a PAC, and it can also be easily estimated noninvasively. ${ }^{26}$ Numerical values are useful, but analysis of the waveform may better identify the mechanism of shock. For instance, as right ventricular dysfunction progresses, the right atrial pressure waves seen in the CVP trace change with the "v" wave becoming progressively higher than the "a" wave. In progressive right ventricular failure, the pulmonary artery pressure will be reduced and can even pseudo-normalize as the right ventricle is unable to generate sufficient pressure. Large "v" waves present in the wedged PAC trace can represent either mitral regurgitation or severe left ventricular diastolic dysfunction, each of which requires different treatments (Fig. 10). The PAC can be useful in determining $\mathrm{CO}$ and its response to therapeutic interventions such as inotropic agents, but its use is declining. Nevertheless, these central catheters have only a limited ability to diagnose a specific cardiac lesion. For example, in the hemodynamic state associated with a low $\mathrm{CO}$, elevated 

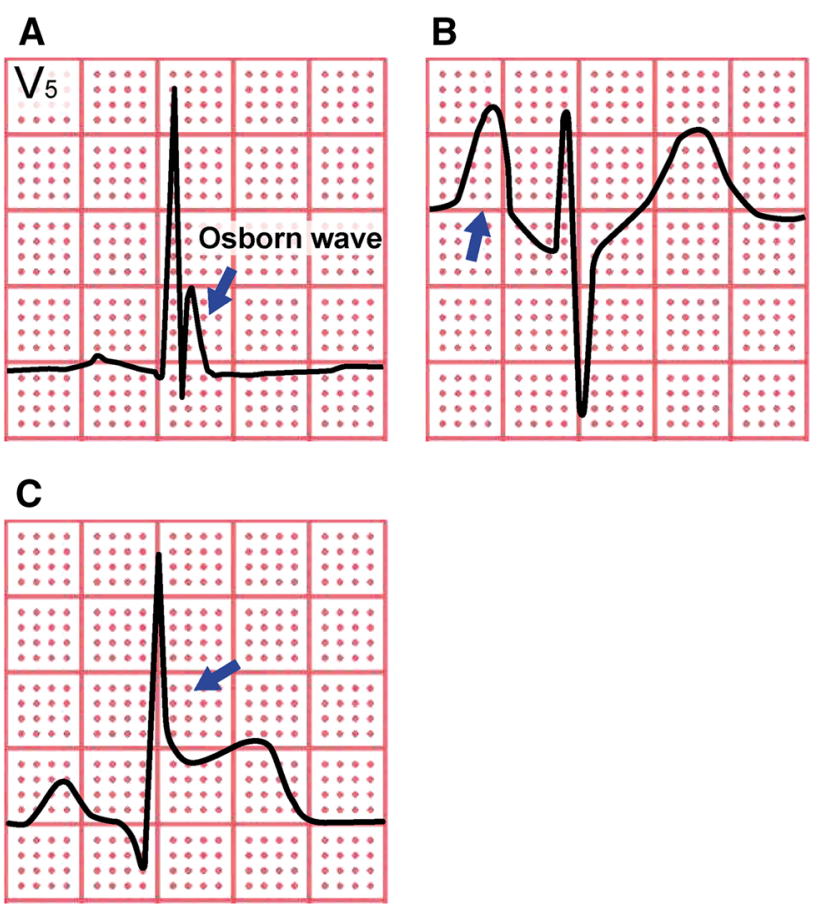

Fig. 7 Electrocardiogram changes. A) Osborn wave is a positive deflection at the junction between the QRS complex and the ST segment. It may be present in hypothermia $\left(<32^{\circ} \mathrm{C}\right)$, hypercalcemia, and brain injury. B) The $\mathrm{P}$ pulmonale wave is a peaked $\mathrm{P}$ wave (height $>2.5 \mathrm{~mm}$ ) that indicates right atrial enlargement, often seen with cor pulmonale (See video 7B1, 7B2, and 7B3 of a patient with acute pulmonary embolism). C) An elevated ST and T wave may be present with acute myocardial ischemia and brain-heart syndrome

Modifications électrocardiographiques. A) Une onde d'Osborn est une déflexion positive à la jonction du complexe QRS et du segment ST. Cela peut être retrouvé en cas d'hypothermie $\left(<32{ }^{\circ} \mathrm{C}\right)$, d'hypercalcémie et de lésion cérébrale. B) L'onde p pulmonaire est une onde $\mathrm{p}$ pointue (hauteur $>2,5 \mathrm{~mm}$ ) qui indique une dilatation de l'oreillette droite. On l'observe souvent dans les cas de cœur pulmonaire (voir les vidéos 7B1, 7B2 et 7B3 d'un patient atteint d'embolie pulmonaire). C) Un segment ST élevé et une onde T peuvent être constatés en cas d'ischémie myocardique aiguë et de syndrome « cerveau-cœur»

pulmonary artery occlusion pressure alone cannot differentiate if cardiac failure is due to systolic (right ventricular and left ventricular) or diastolic dysfunction. In order to improve the diagnostic ability of the PAC, we have described how to use monitoring of right ventricular pressure $^{21}$ as a very promising modality for diagnosing dysfunction of the right ventricle and obstruction of the right ventricular outflow tract as well as for monitoring responses to therapy. ${ }^{17,21}$

Finally, NIRS has been introduced as a monitoring modality during cardiac and noncardiac surgery and also in the ICU. ${ }^{27}$ As with capnography, NIRS measurements can be influenced by CO. Low NIRS readings during cardiac arrest have prognostic value. ${ }^{28}$ It can be comparable to a noninvasive venous blood gas monitor. It also has the unique advantage of providing regional information about specific tissue perfusion, not only for the brain but also for the extremities. ${ }^{29}$ Cerebral NIRS will be influenced by the same variables determining oxygen transport as well as ventilation.

\section{Reliability of arterial pressure monitoring}

An important and often neglected step in managing hemodynamically unstable patients is to make sure that the arterial pressure value is reliable. Suspicion of pseudoarterial hypotension should be raised if there is a discrepancy between the severity of the hypotension and the patient's clinical condition. There can be several mechanisms to explain this phenomenon. Significant arterial pressure differences can be observed between the extremities in older patients and those with vascular disease. If unrecognized, this can lead to the inappropriate use of vasoactive agents. In addition, for unclear reasons, the use of vasoactive agents can cause significant radial to femoral artery pressure gradients. ${ }^{30}$ The diagnosis of this condition was the topic of an article in a previous issue of the Journal. ${ }^{31}$ Also, regular re-zeroing of the arterial transducer is necessary to avoid misdiagnosis due to incorrect calibration. Finally, it is also important to ensure that the position of the transducer is at the level of the right atrium and to adjust it with changes in patient position.

\section{Initial approach to the shock patient}

Once hypotension is confidently confirmed, and in the presence of signs of shock, the airway-breathing-circulation (ABC) approach should then follow. Airway management is crucial because uncorrected hypoxemia will increase right atrial pressure and exacerbate cardiogenic shock. In addition, any shock state can cause hypoperfusion of the respiratory muscles regardless of the etiology, and this can lead to acute hypoventilation and hypoxemia. In the "A" category, we also suggest adding antibiotics, as this is the only efficacious treatment for septic shock. This is important because the mortality from hypotension in septic shock increases by 6-7\% per hour. ${ }^{9}$ Blood cultures should be drawn just before the expeditious administration of broad-spectrum antibiotics. The " $\mathrm{B}$ " is representative of breathing. If acute and uncorrected, inadequate ventilation can lead to hypercapnia, pulmonary hypertension, increased right atrial pressure with right ventricular failure in susceptible patients. Supportive ventilation is adjusted according to the underlying condition. Many acute hemodynamically unstable conditions are associated with reduced Pms; therefore, fluid administration should always be considered as an initial step to support the circulation. Nevertheless, the 


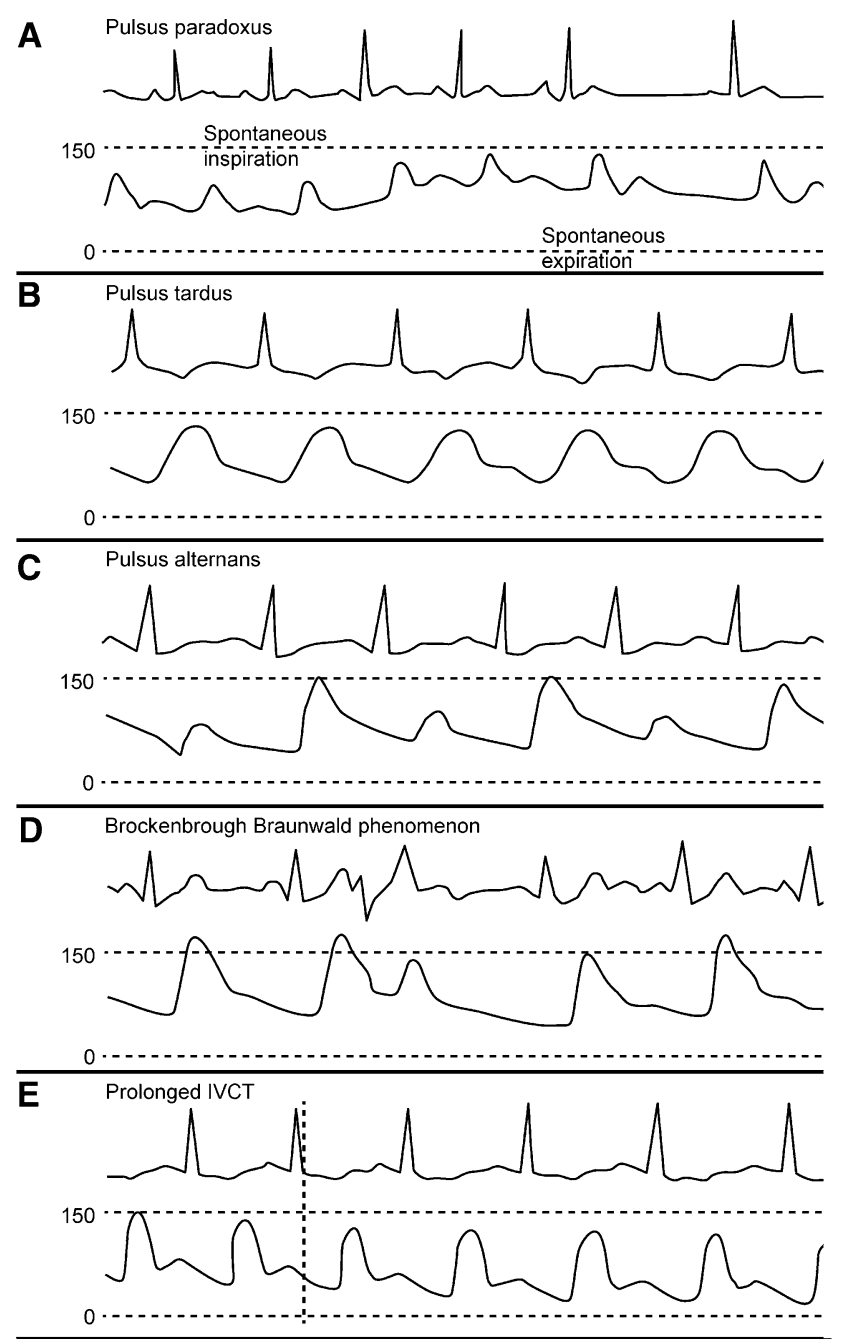

Fig. 8 Arterial pressure waveforms. A) Pulsus paradoxus is the respiratory variation of the pressure waveform which can be present with all three mechanisms of shock: 1) reduced mean systemic venous pressure from hypovolemia, 2) increased right atrial pressure from severe right heart failure with an under-filled left ventricle, and 3) increased resistance to venous return from severe bronchospasm (See video 8a). B) Pulsus tardus is a slow rising pulse with an anacrotic notch that is typically associated with aortic stenosis but can be present in severe left ventricular failure (See video 8b). C) Pulsus alternans, an alternating of weak and strong arterial waveforms, is often associated with severe left ventricular failure (See video 8c). D) Brockenbrough-Braunwald phenomenon is the decrease in arterial pressure associated with the first systole after a premature ventricular contraction, which is pathognomonic of left ventricular outflow tract obstruction (See video 8d). E) Prolonged isovolumic contraction time causes a delay between the QRS and the beginning of the arterial pressure waveform which can be seen in left ventricular failure (See videos 8e). (Adapted with permission from ${ }^{34}$ )
Tracés de la pression artérielle. A) Un pouls paradoxal est caractérisé par une variation du tracé de pression artérielle associée à la respiration. On peut le retrouver avec les trois mécanismes de l'état de choc: 1) pression veineuse systémique moyenne abaissée par hypovolémie, 2) pression de l'oreillette droite augmentée du fait d'une défaillance cardiaque droite sévère avec ventricule gauche sous-rempli et 3) augmentation de la résistance au retour veineux due à un bronchospasme sévère (voir la vidéo 8a). B) Le " pulsus tardus » est un pouls de montée lente avec une encoche qui est typiquement associée à la sténose de la valve aortique, mais peut être aussi retrouvée en cas d'insuffisance ventriculaire gauche sévère (voir la vidéo $8 \mathrm{~b}$ ). C) Dans le pouls alternant, les ondes d'amplitude haute et basse se succède sans cesse. Il est souvent associé à une insuffisance ventriculaire gauche (voir la vidéo 8c). D) Le phénomène de Brockenbrough-Braunwald est la baisse de la pression artérielle associée à la première systole suivant une contraction ventriculaire prématurée, ce qui est pathognomonique d'une obstruction de la chambre de chasse du ventricule gauche (voir la vidéo 8d). E) Un temps de contraction isovolumétrique allongé provoque un écart entre le QRS et le début de l'onde de pression artérielle que l'on peut observer en cas d'insuffisance ventriculaire gauche (voir les vidéos 8e). (Adapté avec l'autorisation $\mathrm{de}^{34}$ ) 


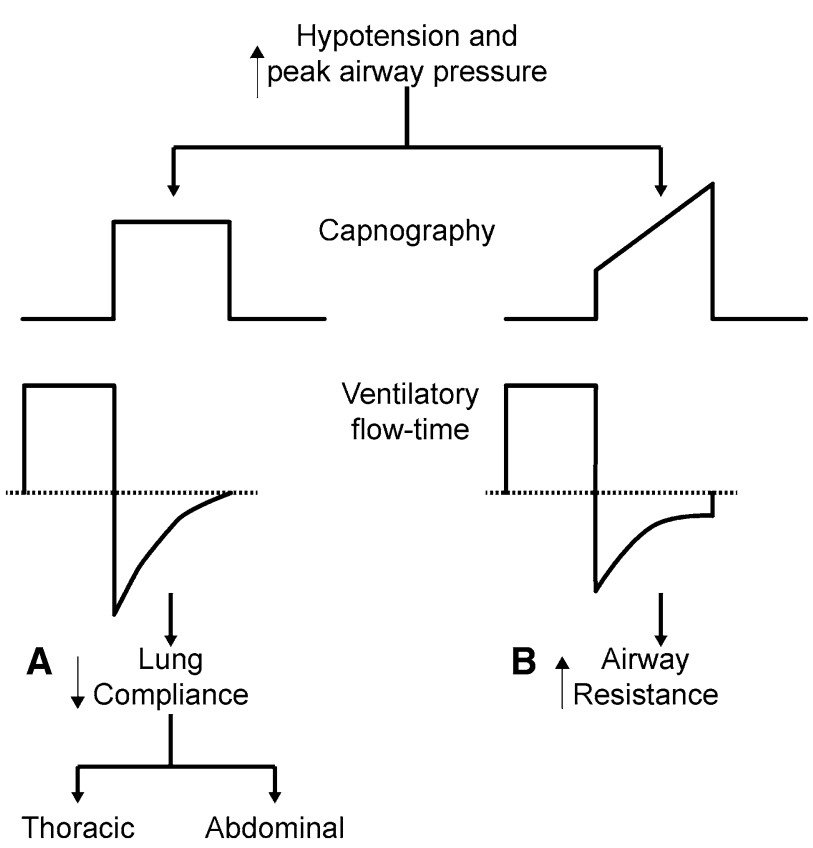

Fig. 9 Capnography and ventilator flow-time waveforms. High airway pressure increases resistance to venous return, often causing hypotension, and the cause can be identified by inspection of both the capnography and ventilator flow-time waveforms. A) With reduced lung compliance from either thoracic or abdominal causes, the capnograph waveform is normal with a horizontal expiratory phase, and the ventilator flow-time waveform is normal or with shortened expiration. B) With increased airway resistance, the capnograph waveform will show a typical prolonged expiratory phase or oblique slope, which is also reflected in the prolonged ventilator flow-time waveform. In this situation, a rapid respiratory rate may cause intrinsic positive end-expiratory pressure (auto-PEEP) to develop. Disconnecting the endotracheal tube from the ventilator or prolonging the expiratory time can correct the hypotension if the mechanism is auto-PEEP (See video 9 of a patient with acute status asthmaticus)

Tracés de capnographie et courbe de débit ventilatoire. Une pression élevée dans les voies aériennes augmente la résistance au retour veineux, provoquant souvent une hypotension dont la cause peut être identifiée par l'inspection des tracés de capnographie et de débit du ventilateur. A) Avec une compliance pulmonaire réduite d'origine thoracique ou abdominale, le tracé du capnographe est normal avec une phase expiratoire horizontale. Le tracé débit-temps du ventilateur est aussi normal ou présente une expiration raccourcie. B) Avec une augmentation de la résistance des voies aériennes, le tracé de capnographie présente une phase expiratoire prolongée typique ou une pente oblique, ce qui se reflète également dans le tracé débit-temps prolongé du ventilateur. Dans cette situation, une fréquence respiratoire élevée peut causer le développement d'une pression positive de fin d'expiration intrinsèque (auto-PEEP). Le débranchement du tube endotrachéal du ventilateur ou la prolongation du temps expiratoire peut corriger l'hypotension si le mécanisme est l'auto-PEEP (voir la vidéo 9 d'un patient présentant un status asthmaticus aigu)

patient's response to fluid should be determined so as to avoid excessive fluid administration in conditions where it is not required (e.g., severe right ventricular failure, left ventricular systolic and diastolic failure, and vasodilatation in the setting of a high $\mathrm{CO}$ ). The selection of the type of fluid remains controversial and is a subject of debate, ${ }^{32}$ but crystalloids are usually used. Finally, vasopressors are introduced concomitantly. Noradrenaline is used as a firstchoice agent unless the patient has symptomatic bradycardia. ${ }^{33}$

If these initial steps lead to successful restoration of the arterial pressure and the mechanism of shock is clearly apparent, then the patient should be followed closely. If, however, this approach fails and vasoactive support is increasing, then a bedside ultrasound examination should be performed, ${ }^{12}$ as will be described in the second of this two-CPD module series on hemodynamic instability.

\section{Clinical case}

A 67-yr-old woman weighing $48 \mathrm{~kg}$, with diabetes, chronic obstructive pulmonary disease and coronary artery disease presents to hospital with an acute abdomen. A diagnosis of bowel perforation with peritonitis is confirmed with computed tomography. In the operating room, following the induction of anesthesia, the systolic blood pressure is $80 \mathrm{mmHg}$ using a radial artery catheter with a heart rate of 110 beats $\cdot \mathrm{min}^{-1}$. The patient responds to the administration of fluid and remains stable throughout the procedure. However at the end of the case, during abdominal closure, she becomes hypotensive and no longer responds to fluid administration. Noradrenaline is started and despite escalating doses her systolic blood pressure remains $85 \mathrm{mmHg}$. Her end-tidal is $37 \mathrm{mmHg}$ with a minute ventilation of $6 \mathrm{~L} \cdot \mathrm{min}^{-1}$.

\section{Instructions for completing the Continuing Professional Development (CPD) module:}

1. Read the current article and the references indicated in bold.

2. Go to: http://www.cas.ca/Members/CPD-Online and select the current module (Bedside clinical \& ultrasound-based approaches to shock - Part I: Focus on the clinical approach).

3. Answer the multiple choice questions regarding the case scenario.

4. Once you have entered all of your answers, you will have access to experts' explanations for all the possible choices.

5. Participants may claim up to four hours of CPD for a total of 12 credits under Section 3 of the CPD program of the Royal College of Physicians and Surgeons of Canada. 

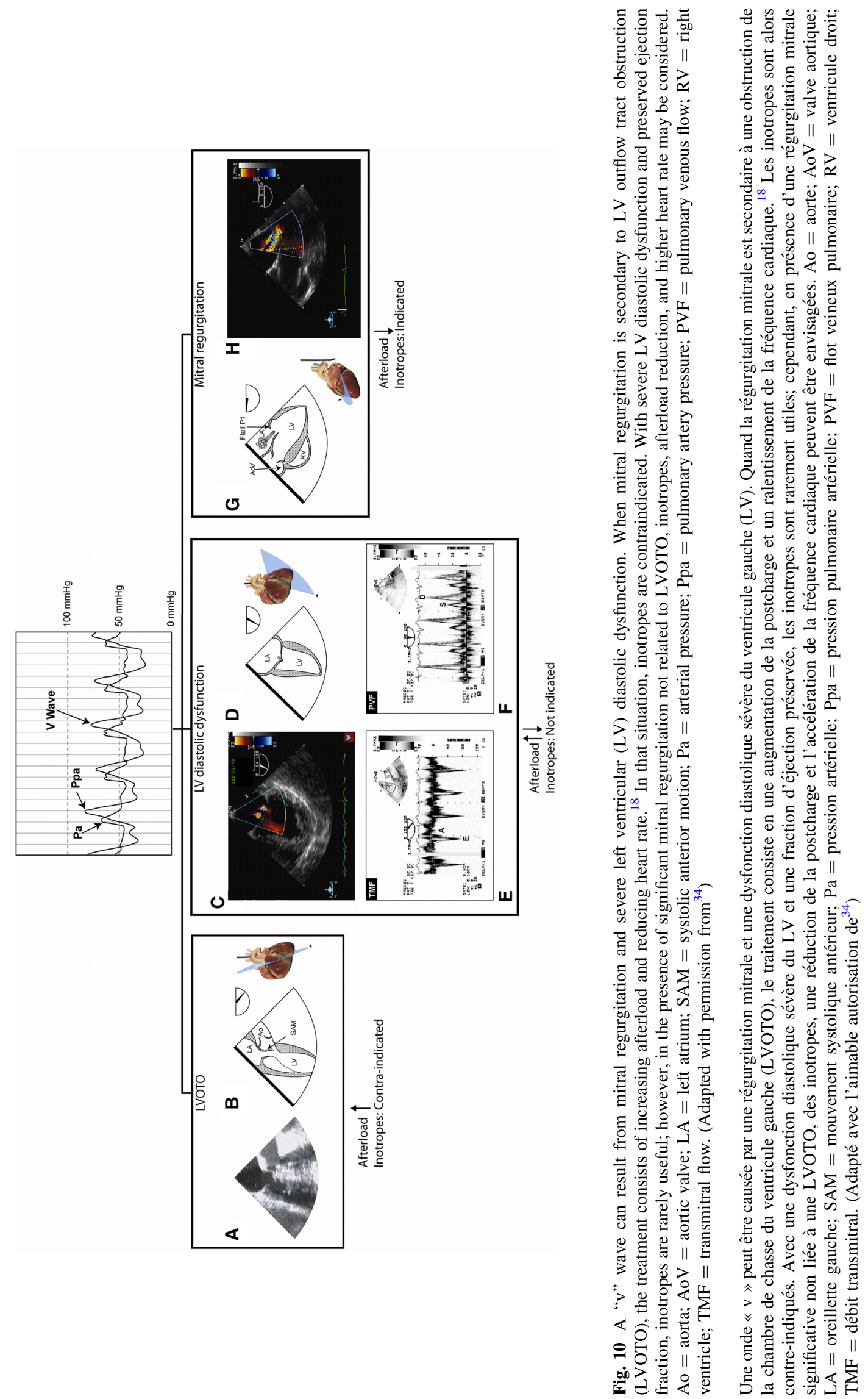


\section{Approches cliniques et échographiques au chevet du patient pour la gestion de l'instabilité hémodynamique - Partie 1: L'approche clinique}

Résumé Le choc est défini comme étant une situation où le transport de l'oxygène est insuffisant pour répondre aux besoins en oxygène de l'organisme. La compréhension des mécanismes entraînant la baisse du débit cardiaque, un déterminant du transport de l'oxygène, est essentielle pour initier une thérapie adaptée à la gestion du choc. La combinaison du concept de retour veineux avec le rapport pression-volume ventriculaire est une méthode utile pour apprécier la physiologie circulatoire complexe au cours du choc. Des indices fournis par les antécédents du patient, l'examen physique et des tests de laboratoire essentiels, ainsi que par l'inspection soigneuse des tracés hémodynamiques, électrocardiographiques et respiratoires, peuvent aider à identifier l'étiologie et le ou les mécanismes du choc. Une réanimation générale peut commencer après avoir vérifié la pression artérielle à plus d'un site, puis un traitement plus spécifique peut être entrepris pour gérer le choc. Si le patient ne répond pas à ces mesures, un examen échographique peut alors être réalisé pour déterminer plus précisément le ou les mécanismes et l'étiologie du choc.

Objectif Développer une méthode d'approche pour la gestion d'un patient hémodynamiquement instable.

\section{Objectifs de ce module de développement professionnel continu (DPC):}

Après avoir lu ce premier module, le lecteur doit être capable de:

1. Identifier les trois déterminants du retour veineux.

2. Énumérer les diverses étiologies du choc en utilisant le concept de retour veineux.

3. Corréler les déterminants du retour veineux avec la boucle pression-volume ventriculaire et l'évaluation de la veine cave inférieure.

4. Identifier certains aspects du tracé hémodynamique (pression artérielle, pression veineuse centrale et pression capillaire pulmonaire) qui sont associés à des causes spécifiques de choc.

5. Déterminer la valeur des tracés capnographiques et respiratoires pour l'identification du mécanisme du choc.

6. Décrire et intégrer les étapes importantes pour l'évaluation du patient en état de choc avant de réaliser une échographie à son chevet.
Première partie: Mise au point sur l'approche clinique

Importance de l'instabilité hémodynamique

L'hypotension est définie par une pression artérielle basse et est fréquente chez les patients pris en charge en salle d'opération et en unité de soins intensifs (USI). Dans une étude de Walsh et coll. sur 18989 patients de chirurgie non cardiaques, une pression artérielle moyenne inférieure à $55 \mathrm{mmHg}$ est survenue en cours d'intervention pendant au moins cinq minutes chez $43 \%$ des patients et elle a duré plus de 20 minutes chez 10,4\% des patients de cette cohorte. ${ }^{1}$ L'instabilité hémodynamique est la présence d'une hypotension persistante et elle peut aboutir à un état de choc. Le choc est défini comme étant une affection au cours de laquelle le transport de l'oxygène est insuffisant pour répondre aux besoins en oxygène de l'organisme. L'hypotension ne provoque pas toujours une hypoperfusion ou un état de choc, bien que plusieurs études aient montré son association avec les accidents vasculaires cérébraux (AVC) ischémiques, ${ }^{2}$ les lésions myocardique, ${ }^{1}$ l'insuffisance rénale ${ }^{3}$ et l'augmentation de la mortalité dans la chirurgie non cardiaque. ${ }^{4}$ Dans le contexte de la chirurgie cardiaque, l'instabilité hémodynamique se manifeste par le sevrage difficile de la circulation extracorporelle ou par un syndrome de bas débit cardiaque bien que l'hypotension soit le plus souvent due à la vasodilatation. La présence d'un syndrome de bas débit cardiaque est associée à une morbidité et mortalité postopératoires significatives. ${ }^{5,6}$

Une instabilité hémodynamique prolongée peut être plus dangereuse qu'un bref épisode d'hypotension, en particulier chez les personnes âgées. ${ }^{7}$ La durée du choc est un déterminant majeur de la survie en cas de traumatisme, ${ }^{8}$ choc septique, ${ }^{9}$ infarctus du myocarde ${ }^{10}$ et AVC. ${ }^{11}$ Cela a conduit à la création du terme "heure critique » ou « golden hour » qui implique qu'un choc prolongé de plus d'une heure peut léser les différents organes et aboutir au décès du patient. Il est important que les cliniciens prenant en charge un patient hémodynamiquement instable identifient rapidement le ou les mécanismes du choc pour pouvoir entamer sans retard le traitement le plus adapté. Une fois les étapes élémentaires initiales entreprises chez tout patient en état de choc, le recours à l'échocardiographie au chevet doit être envisagé le plus tôt possible afin de clarifier le diagnostic et faciliter le traitement. ${ }^{12}$

Dans cette série de deux modules de développement professionnel continu (DPC), nous proposons une approche diagnostique et thérapeutique pour faciliter la prise en charge des patients hémodynamiquement instables. Dans le premier module de DPC, nous présentons les principes physiopathologiques de base du mécanisme du choc. Nous reverrons, en outre, quelques signes cliniques et indices 
Tableau 1 Classification des états de chocs au moyen du concept de retour veineux

\begin{tabular}{|c|c|c|}
\hline $\begin{array}{l}\text { Pression veineuse systémique moyenne } \\
\text { abaissée }\end{array}$ & Pression de l'oreillette droite augmentée & Résistance augmentée au retour veineux \\
\hline $\begin{array}{l}\text { Choc hémorragique/hypovolémique } \\
\text { - Externe } \\
\text { - Interne: thorax, abdomen } \\
\text { Choc distributif } \\
\text { - Choc septique et syndrome toxique } \\
\text { - Non-septique: } \\
\text { - Anaphylactique } \\
\text { - Endocrinien: } \downarrow \text { fonction surrénalienne et } \\
\text { thyroïdienne } \\
\text { - Choc neurogénique et bloc de l'axe } \\
\text { central } \\
\text { - Pharmacologique and toxique } \\
\text { - Post RCR et CEC } \\
\text { - Réactions inflammatoires : brulés, } \\
\text { pancréatite, trauma multiple, SIRS }\end{array}$ & $\begin{array}{l}\text { Dysfonction systolique et diastolique } \\
\text { (ischémique ou non-ischémique) } \\
\text { Insuffisance valvulaire aiguë } \\
\text { Obstruction d'une chambre de chasse } \\
\text { ventriculaire } \\
\text { Embolie pulmonaire } \\
\text { Hypoxémie et hypercapnie }\end{array}$ & $\begin{array}{l}\text { Extrinsèque: } \\
\text { - Supra-diaphragmatique: } \\
\text { - tamponnade } \\
\text { - pneumothorax } \\
\text { - tamponnade médiastinale } \\
\text { - hyperinsufflation sévère (auto-PEEP) } \\
\text { - Sous-diaphragmatique: } \\
\text { - syndrome du compartiment abdominal } \\
\text { (endoluminal, extraluminal et pariétal) } \\
\text { Intrinsèque: Obstruction de la VCI due à des } \\
\text { sutures, tumeurs, dispositifs }\end{array}$ \\
\hline
\end{tabular}

$\mathrm{RCR}$ = réanimation cardiorespiratoire; $\mathrm{CEC}=$ circulation extra-corporelle; $\mathrm{VCI}=$ veine cave inférieure; PEEP $=$ Pression positive en fin d'expiration; SIRS = systemic inflammatory response syndrome

observés sur le monitorage qui peuvent orienter le clinicien vers un diagnostic spécifique. Dans le second module de DPC, nous nous concentrerons sur l'intégration de l'échographie cardiaque, pulmonaire, abdominale et vasculaire effectuée au chevet du patient pour l'identification des mécanismes et de l'étiologie sous-jacente du choc.

\section{L'approche physiopathologie du choc}

Pour aider à identifier le mécanisme du choc, nous combinons trois éléments complémentaires: A) le concept de retour veineux; B) la relation pression-volume ventriculaire; et C) l'utilisation de l'échographie au chevet du patient. ${ }^{13}$ L'évaluation hémodynamique du choc commence souvent par la détermination des paramètres suivants: débit cardiaque, fréquence et rythme cardiaque, précharge, postcharge et contractilité. Le débit cardiaque représente le sang pompé par le cœur, ce qui, dans un système cardiovasculaire fermé, doit être égal au retour veineux vers le cœur. Le concept de retour veineux aide à décrire la contribution du volume sanguin et de la capacitance veineuse dans les mécanismes du choc.

\section{Concept du retour veineux}

Dans un article d'un précédent numéro du Journal, ${ }^{14}$ nous avons montré comment le concept de retour veineux peut expliquer le mécanisme du choc chez des patients présentant un syndrome du compartiment abdominal. Une approche simplifiée de ce concept est présentée dans la Figure 1A. La description détaillée du concept de retour veineux dépasse le cadre de cet article, mais les lecteurs intéressés pourront se reporter aux deux excellentes analyses de Jacobsohn et Funk. ${ }^{15,16}$

En termes simples, le retour veineux (VR) est déterminé par un gradient de pression. Ce gradient correspond à la différence entre la pression veineuse systémique moyenne (Pms) à la périphérie et la pression dans l'oreillette droite (Pra). Le retour veineux est également inversement proportionnel à la résistance au retour veineux (Rvr).

$\mathrm{VR}=\frac{\text { Pms }- \text { Pra }}{\text { Rvr }}$

Donc le retour veineux, puis le débit cardiaque seront réduits si: 1) la pression veineuse systémique est basse, 2 ) la pression de l'oreillette droite est augmentée, et/ou 3) il existe une augmentation de la résistance au retour veineux. La relation existant entre le retour veineux et le débit cardiaque peut être montrée sur un graphique simple (Fig. 1B). La Figure 2 illustre comment des baisses comparables du retour veineux et, par conséquent, du débit cardiaque secondaires à trois mécanismes différents altéreront ce graphique.

$\mathrm{La}$ pression veineuse systémique dépend du statut volumique et de la compliance du réservoir veineux. Elle peut ainsi être abaissée à la fois par un choc hémorragique 
Tableau 2 Éléments clés de l'évaluation d'un patient hémodynamiquement instable

\begin{tabular}{|c|c|c|c|}
\hline & Pression veineuse systémique moyenne abaissée & $\begin{array}{l}\text { Pression de l'oreillette } \\
\text { droite augmentée }\end{array}$ & Résistance augmentée au retour veineux \\
\hline $\begin{array}{l}\text { Antécédents et histoire } \\
\text { de la maladie }\end{array}$ & $\begin{array}{l}\text { Médicaments (antihypertenseurs, corticostéroïdes, } \\
\text { antibiotiques, anticoagulants) } \\
\text { Comorbidités (cirrhose) } \\
\text { Histoire médicale ancienne et récente (procédures } \\
\text { abdominales ou thoraciques), } \\
\text { Bloc neuraxial }\end{array}$ & $\begin{array}{l}\text { Médicaments } \\
\quad \text { (anti-arythmiques; } \\
\text { bêta-bloqueurs) } \\
\text { Maladie coronarienne } \\
\text { Hypertension } \\
\text { AVC aigu } \\
\text { Immobilisation prolongée } \\
\text { Thrombophilie }\end{array}$ & $\begin{array}{l}\text { Procédure abdominale récente } \\
\text { Accès veineux central } \\
\text { Chirurgie impliquant la VCI }\end{array}$ \\
\hline Examen & $\begin{array}{l}\text { Température cutanée élevée } \\
\text { Signe de Grey Turner ou ecchymoses aux flancs } \\
\text { Signes de cirrhose } \\
\text { Râles bronchiques }\end{array}$ & $\begin{array}{l}\text { Température cutanée basse } \\
\text { Déficits neurologiques } \\
\quad \text { focaux ou généraux } \\
\text { Hippocratisme digital } \\
\text { Souffle cardiaque }\end{array}$ & $\begin{array}{l}\text { Température cutanée basse } \\
\text { Abdomen tendu } \\
\text { Bruits cardiaques étouffés/lointains à } \\
\text { l'auscultation } \\
\text { Diminution unilatérale du murmure vésiculaire } \\
\text { à l'ausculation des poumons }\end{array}$ \\
\hline Tests complémentaires & $\begin{array}{l}\text { FSC } \\
\text { Potassium, glucose } \\
\text { Hémoculture } \\
\text { Profil de coagulation } \\
\text { Amylase } \\
\text { Procalcitonine }\end{array}$ & $\begin{array}{l}\mathrm{CK} \text {, troponine } \\
\mathrm{ECG} \text { à } 12 \text { dérivations }\end{array}$ & $\begin{array}{l}\text { Radiographies du thorax et de l'abdomen } \\
\text { Gaz du sang artériel }\end{array}$ \\
\hline
\end{tabular}

D'autres indicateurs utiles de la sévérité du choc incluent: les signes vitaux, créatinine, les enzymes hépatiques, la mesure du lactate, de la saturation veineuse en oxygène du gaz veineux, la différence veno-artérielle du dioxyde de carbone. $\mathrm{AVC}=$ accident vasculaire cérébral; $\mathrm{CK}=$ créatinine kinase; $\mathrm{ECG}=$ électrocardiogramme; $\mathrm{FSC}=$ formule sanguine complète; $\mathrm{VCI}=$ veine cave inférieure

et un choc distributif. La courbe du retour veineux dans le choc hémorragique est modifiée pour représenter une baisse du retour veineux (décalage vers la gauche avec une pente inchangée), un débit cardiaque réduit (pente de Starling inchangée) et une pression de l'oreillette droite également réduite (Fig. 2 et $3 \mathrm{~A}$ ).

$\mathrm{Au}$ cours du choc cardiogénique, la pression de l'oreillette droite est élevée. Le choc cardiogénique peut être la conséquence d'une dysfonction systolique ventriculaire gauche et droite, d'une dysfonction diastolique, d'une obstruction dans la chambre de chasse $\mathrm{du}$ ventricule gauche ou droit, ${ }^{17,18}$ d'une insuffisance valvulaire aiguë et d'une embolie pulmonaire. L'hypoxémie et l'hypercapnie, si elles sont aiguës et non corrigées, entraîneront une hypertension pulmonaire aboutissant à une augmentation de la pression auriculaire droite; en l'absence de traitement chez des patients prédisposés, cela aboutira à une insuffisance cardiaque droite. La courbe du retour veineux avec dysfonction systolique ou contractilité réduite montre une réduction du retour veineux (décalage vers la droite de la courbe du retour veineux), un débit cardiaque abaissé (pente de la courbe de Starling réduite), une augmentation de la pression auriculaire droite (Fig. 2), et une augmentation compensatrice de la pression veineuse systémique moyenne. Une augmentation de la contractilité avec des inotropes augmentera le retour veineux par une baisse de la pression dans l'oreillette droite (Fig. 3B). L'effet de la modification de la postcharge ou de la résistance périphérique totale sur le retour veineux et le débit cardiaque est présenté sur la Fig. 3C.

Le meilleur exemple d'une augmentation aiguë de la résistance au retour veineux est l'hypotension par compression de la veine cave inférieure chez la femme enceinte. D'autres exemples incluent le syndrome aigu du compartiment abdominal, ainsi que la tamponnade, le pneumothorax et l'hyperinsufflation qui accompagne une pression positive de fin d'expiration (PEEP) intrinsèque, bien que dans ces trois derniers cas, leur effet s'exerce également par le biais de l'augmentation de la pression dans l'oreillette droite. Une augmentation de la résistance au retour veineux provoque un choc en empêchant le sang de revenir au cœur en dépit d'une fonction cardiaque et d'un volume sanguin normaux. La résistance augmentée au retour veineux crée une courbe (Fig. 2) qui montre la réduction du retour veineux (modification de la pente de la courbe du retour veineux), un débit cardiaque réduit (réduction de la pente de la courbe de Starling), une augmentation de la pression auriculaire droite et une augmentation de la pression veineuse systémique moyenne. La pression pleurale augmentée avec pneumothorax, par exemple, devient le facteur limitant du retour veineux (Fig. 3D). Cela peut 
expliquer pourquoi le soulagement d'un pneumothorax ou d'une tamponnade peut, chez certains patients, augmenter significativement le retour veineux. En effet, l'augmentation brutale du gradient entre la pression systémique veineuse moyenne et celle de l'oreillette droite qui survient alors peut provoquer un accroissement important du retour veineux. En conséquence, certains patients pourraient développer une insuffisance ventriculaire droite aiguë et un œdème pulmonaire par exacerbation de la dysfonction diastolique du ventricule gauche à la suite du traitement de ces affections. Ce mécanisme explique également en partie ce que l'on appelle l'œè̀me pulmonaire de réexpansion.

Il y a cependant des cas dans lesquels plusieurs éléments relatifs à la courbe de retour veineux sont altérés. Par exemple, certains agents inotropes ne modifient pas uniquement la contractilité, mais entraînent aussi une baisse de la résistance au retour veineux par le biais de la vasodilatation périphérique. Une baisse de la pression veineuse systémique moyenne peut alors survenir si le patient est hypovolémique. ${ }^{15}$ De plus, des affections pulmonaires, telles qu'un pneumothorax, peuvent comprimer le cœur (comme le ferait une tamponnade) tandis que l'hypoxémie associée peut, de son côté, provoquer une hypertension pulmonaire et une élévation de la pression de l'oreillette droite. Le Tableau 1 résume les causes les plus fréquentes de choc selon le concept de retour veineux.

\section{Relation pression-volume ventriculaire}

La relation existant entre la fonction ventriculaire et le statut hémodynamique peut s'exprimer sous forme de boucle pression-volume. Ces courbes montrent une description graphique de la fonction ventriculaire en affichant le volume d'un seul cycle cardiaque par rapport à la pression en fonction du temps (Fig. 4A). Cette boucle est caractérisée par sept événements temporels. Bien que la boucle pression-volume puisse être obtenue par des mesures continues de la pression et du volume, cela est rarement fait en pratique clinique. Les déterminants individuels de la boucle pression-volume peuvent être obtenus en utilisant 1) l'échocardiographie pour évaluer le volume des cavités cardiaques, 2) un cathétérisme de l'artère pulmonaire pour estimer les pressions de remplissage et 3) un cathétérisme artériel pour mesurer les pressions systémiques (Fig. 4B).

\section{Évaluation de la veine cave inférieure}

Enfin, l'échocardiographie au chevet du patient est utile à deux niveaux. Premièrement, elle peut permettre d'identifier rapidement le mécanisme du choc et, deuxièmement, elle peut aussi permettre d'identifier son étiologie sous-jacente. La méthode la plus rapide pour identifier le mécanisme du choc consiste à examiner la veine cave inférieure. Il y a des limites à l'examen de la veine cave inférieure pour l'estimation de la pression veineuse systémique moyenne. Elles seront discutées dans le second module de DPC de cette série en deux parties sur les approches clinique et échographique de l'instabilité hémodynamique au chevet du patient.

La Fig. 5 résume la stratification du choc en intégrant un examen échographique de la veine cave inférieure, la boucle pression-volume et le concept de retour veineux. Le mécanisme du choc résultant d'une augmentation de la résistance au retour veineux est plus complexe et des exemples spécifiques seront proposés dans le second module de DPC. D'autres signes cliniques se rapportant à la réduction de la pression veineuse systémique moyenne, l'hypovolémie ou la réponse à l'administration de liquide ont récemment fait l'objet d'une revue. ${ }^{19}$

Approche pratique du choc au chevet du patient en utilisant l'échographie Une approche des patients hémodynamiquement instables est proposée à la Fig. 6 . Le Tableau 2 résume quelques éléments clés qui peuvent être utilisés pour évaluer le mécanisme du choc.

\section{Antécédents, examen physique et tests de laboratoire de base}

Les antécédents du patient peuvent fournir une information cruciale pour gérer l'instabilité hémodynamique. Malheureusement, des informations utiles ne peuvent pas toujours être obtenues d'un patient dans un état instable; ainsi, celles-ci doivent provenir d'autres sources, y compris la famille et les amis du patient. L'analyse du dossier médical est recommandée, mais s'avère difficile pendant la ressuscitation. Une attention particulière doit être accordée à l'utilisation de drogues qui peut compliquer la ressuscitation.

Un examen physique rapide du patient doit être effectué sans retard afin de documenter les signes cliniques de choc, évaluer le statut neurologique, examiner le système cardiopulmonaire, évaluer la compliance abdominale et inspecter les extrémités. L'observation clinique d'une inégalité pupillaire, d'une éruption cutanée, de signes de cirrhose, d'ecchymoses aux flancs (signe de Grey Turner) ou d'œdème des jambes peut aider à orienter le diagnostic.

Les tests de laboratoire de dépistage tels que la formule sanguine complète, les électrolytes, le glucose, la troponine et les gaz artériels peuvent fournir des renseignements intéressants. Néanmoins, les résultats de ces tests sont rarement immédiatement disponibles, sauf en cas d'analyses réalisées au chevet du patient. Les taux de procalcitonine sont maintenant utilisés plus fréquemment dans les unités de soins d'urgence et de soins intensifs afin d'éliminer une infection bactérienne et d'ajuster les antibiotiques. ${ }^{20}$ 


\section{Dispositifs de monitorage}

L'examen soigneux des variables numériques continues et des tracés affichés sur le moniteur peut également orienter sur le mécanisme du choc. Les variables habituellement affichées sont l'électrocardiographie (ECG), l'oxymétrie de pouls, la capnographie ou le taux de dioxyde de carbone en fin de respiration $\left(\mathrm{ETCO}_{2}\right)$, la pression artérielle et les variables du ventilateur (notamment la pression des voies aériennes, le volume et le débit). Chez certains patients, la pression veineuse centrale (PVC) ou la pression dans l'oreillette droite, la pression dans l'artère pulmonaire, la pression dans le ventricule droite, ${ }^{21}$ ainsi que l'oxygénation cérébrale ou d'autres organes par spectroscopie infrarouge (NIRS) peuvent être monitorés.

L'interprétation de la fréquence et du rythme cardiaque à l'ECG avec une analyse du segment ST sont à la base de la réanimation cardiaque avancée. De plus, l'ECG peut révéler des ondes $\mathrm{P}$ pointues suggérant l'embolie pulmonaire aiguë, des ondes $\mathrm{T}$ surélevées dans le syndrome " cerveau-cœur », des ondes d'Osborn dans l'hypothermie et un microvoltage dans la tamponnade (Fig. 7). Une dysfonction cardiaque ventriculaire gauche est plus fréquemment associée à la présence d'un bloc de branche gauche qu'avec un bloc de branche droit. ${ }^{22}$

L'oxymétrie de pouls est utile pour détecter une hypoxémie et le tracé peut procurer, de façon non invasive, l'information obtenue avec un monitorage invasif de la pression artérielle. ${ }^{19}$ Les variations de l'amplitude du signal d'oxymétrie de pouls peuvent indiquer une baisse de la pression veineuse systémique moyenne. ${ }^{23}$ Après l'administration d'un bolus liquidien, une diminution de la variation respiratoire du tracé peut confirmer la réponse positive aux liquides; toutefois, une dysfonction ventriculaire droite doit être suspectée si les variations respiratoires augmentent avec la réanimation liquidienne.

Certaines caractéristiques du tracé de pression artérielle peuvent faciliter l'identification du mécanisme spécifique $\mathrm{du}$ choc. Ce sont, notamment: un pouls alternant (insuffisance ventriculaire gauche), un pouls paradoxal (tamponnade, hypovolémie et aggravation de maladie pulmonaire obstructive chronique [MPOC] $),{ }^{24}$ le «pulsus tardus » (sténose aortique et insuffisance ventriculaire gauche), le pouls «bisferiens » et le phénomène de Brockenbrough-Braunwald. Les deux derniers sont pathognomoniques d'une obstruction de la chambre de chasse du ventricule gauche ${ }^{18}$ (Fig. 8). Le tracé de la pression artérielle peut être analysé seul ou avec d'autres modalités de monitorage telle que l'ECG. On améliore alors la précision du diagnostic dans des situations telles que l'insuffisance ventriculaire gauche (Fig. 8E). Il est important d'insister sur l'obtention de mesures fiables et valides de la pression artérielle.
L'utilisation de la capnographie et de l'analyse du tracé de l'ETCO 2 a fait l'objet de revues approfondies. ${ }^{25} \mathrm{Chez}$ des patients en état de choc, la capnographie peut servir de méthode de monitorage non invasive du débit cardiaque. Des interventions dynamiques telles que de soulever les membres inférieurs peuvent permettre d'évaluer la réponse liquidienne. Si un patient répond aux liquides, le fait de soulever les membres inférieurs augmentera habituellement l'ETCO 2 de $2 \mathrm{mmHg}$ ou plus. ${ }^{19}$ Certains aspects du tracé sont importants à identifier. Une pente ascendante pendant la phase III du tracé est souvent associée à une exacerbation de la MPOC, laquelle risque de provoquer une PEEP intrinsèque ou auto-PEEP. Une pente descendante indique une fuite de gaz (par exemple, par une fistule broncho-pleurale). Enfin, une hypotension aiguë avec une élévation brutale de l'ETCO ${ }_{2}$ au cours d'une laparoscopie ou d'une saphénoscopie est pathognomonique d'une embolie par $\mathrm{CO}_{2}$, laquelle peut provoquer une insuffisance ventriculaire droite aiguë.

Les tracés respiratoires de pression, débit et volume sont utiles pour déterminer si l'augmentation de la pression dans les voies aériennes (qu'elle soit associée ou non à une hypotension) résulte d'une augmentation de la résistance des voies aériennes ou d'une baisse de la compliance pulmonaire. Le graphique volume-pression est un moyen simple permettant de différencier ces deux situations (Fig. 9). En présence d'un pneumothorax ou d'un syndrome du compartiment abdominal, la compliance pulmonaire diminuée réduit la surface du graphique volume-pression et raccourcit le temps expiratoire. Avec l'augmentation de la résistance des voies aériennes liée à une auto-PEEP ou au bronchospasme, la surface du diagramme volume-pression est augmentée et le temps expiratoire prolongé. L'analyse des ces tracés, combinée à la capnographie, s'avère une méthode rapide pour l'établissement d'un diagnostic. Dans les deux cas, la résistance au retour veineux est accrue; toutefois, le traitement du problème sous-jacent est totalement différent.

Chez certains patients, la PVC sera obtenue avec ou sans insertion d'un cathétér de l'artère pulmonaire (CAP) et elle peut aussi être facilement estimée de façon non invasive. ${ }^{26}$ Des valeurs numériques sont utiles, mais l'analyse du tracé de la PVC permet de mieux identifier le mécanisme du choc. Par exemple, l'aspect des ondes composant le tracé de la PVC permet d'identifier la progression d'une dysfonction ventriculaire droite: l'onde $\langle\mathrm{v} »$ devenant progressivement plus haute que l'onde «a ». Dans une insuffisance ventricule droite évolutive, la pression de l'artère pulmonaire sera abaissée et peut même se «pseudo-normaliser» lorsque le ventricule droit devient incapable de générer une pression aéquate. De grandes ondes « V » visibles sur le tracé d'occlusion de l'artère pulmonaire du CAP peuvent être associéees à une 
régurgitation mitrale ou une dysfonction diastolique ventriculaire gauche sévère, conditions qui nécessitent des traitements différents (Fig. 10). Le CAP peut être utile pour déterminer le débit cardiaque et sa réponse aux interventions thérapeutiques comme les agents inotropes, mais son usage est en déclin. Néanmoins, ces cathéters centraux n'ont qu'une capacité limitée pour diagnostiquer une lésion cardiaque spécifique. Par exemple, dans l'état hémodynamique associé à un débit cardiaque bas, la seule augmentation de la pression d'occlusion de l'artère pulmonaire ne permet pas d'attribuer la défaillance cardiaque à une dysfonction systolique (ventriculaire droite ou gauche) ou diastolique. Afin d'améliorer les capacités diagnostiques du CAP, nous avons proposé le monitorage de la pression ventriculaire droite ${ }^{21}$ comme modalité très prometteuse pour le diagnostic de la dysfonction ventriculaire droite et de l'obstruction de la chambre de chasse du ventricule droit, de même que pour le suivi de la réponse thérapeutique. ${ }^{17,21}$

Enfin, la NIRS est une modalité de monitorage applicable à la chirurgie, cardiaque ou non, ainsi qu'à l'USI. ${ }^{27}$ Comme pour la capnographie, les mesures de la NIRS peuvent être influencées par le débit cardiaque. Des valeurs basses de la NIRS au cours d'un arrêt cardiaque ont une valeur pronostique. ${ }^{28}$ Le monitorage de la NIRS peut être comparable à un suivi non invasif des gaz veineux sanguins. La NIRS a également l'avantage unique de fournir des renseignements sur la perfusion tissulaire spécifique d'une région, non seulement pour le cerveau, mais aussi pour les extrémités. ${ }^{29}$ La NIRS cérébrale sera influencée par la ventilation et les mêmes variables déterminant le transport de l'oxygène.

\section{Fiabilité du monitorage de la pression artérielle}

Une étape importante et souvent négligée dans la gestion des patients hémodynamiquement instables est de s'assurer que la valeur de la pression artérielle est fiable. L'existence d'une pseudo-hypotension artérielle doit être suspectée en cas de divergence entre la sévérité de l'hypotension et l'état clinique du patient. Plusieurs mécanismes peuvent expliquer ce phénomène. Des différences significatives de pression artérielle peuvent être observées entre les extrémités chez les patients âgés ou ceux ayant une maladie vasculaire. Si ce problème n'est pas reconnu, cela peut conduire à une utilisation inappropriée d'agents vasoactifs. De plus, pour des raisons mal connues, l'utilisation d'agents vasoactifs peut créer des gradients de pression significatifs entre les artères radiale et fémorale. ${ }^{30}$ Le diagnostic de ce trouble a été le thème d'un article paru dans un précédent numéro du Journal. ${ }^{31}$ Il est également nécessaire de remettre régulièrement à zéro le transducteur artériel afin d'éviter une erreur diagnostique due à un mauvais étalonnage. Enfin, il est également important de s'assurer que le transducteur est positionné au niveau de l'oreillette droite et de l'ajuster avec les changements de position du patient.

\section{Approche initiale d'un patient en état de choc}

Une fois l'hypotension confirmée et en présence de signes de choc, un protocole $\mathrm{ABC}$ (airway-breathing-circulation) doit alors être suivi. La gestion des voies aériennes est cruciale parce qu'une hypoxémie non corrigée augmentera la pression dans l'oreillette droite et exacerbera le choc cardiogénique. De plus, tout état de choc peut entraîner une hypoperfusion des muscles respiratoires, indépendamment de l'étiologie, ce qui peut aboutir à une hypoventilation aiguë et à une hypoxémie. Dans la catégorie « $\mathrm{A}$ » du protocole $\mathrm{ABC}$, nous suggérons également d'ajouter des antibiotiques, car il s'agit du seul traitement efficace du choc septique. Cela est important, car la mortalité par hypotension au cours d'un choc septique augmente de $6 \%$ à $7 \%$ par heure. ${ }^{9}$ Des hémocultures doit être obtenues juste avant l'administration d'antibiotiques à large spectre. Le «B » (pour «breathing ») représente la respiration. En cas de problème aigu et non corrigé de ventilation inadaptée, il peut apparaître une hypercapnie, une hypertension pulmonaire, une augmentation de la pression auriculaire droite avec défaillance ventriculaire droite chez les patients à risque. La ventilation assistée est ajustée en fonction de la condition sous-jacente. Plusieurs états hémodynamiquement instables sont associées à une réduction de la pression veineuse systémique moyenne; il y a donc toujours lieu d'envisager l'administration de liquides comme première étape de soutien circulatoire. Néanmoins, la réponse du patient aux liquides doit être déterminée de façon à éviter une administration excessive dans les cas où le volume n'est pas requis (par exemple, l'insuffisance ventriculaire droite sévère, la défaillance ventriculaire gauche systolique et diastolique, et la vasodilatation dans le cadre d'un débit cardiaque élevé). Le choix du type de liquide reste controversé $^{32}$ mais les solutions cristalloïdes sont habituellement utilisées. Enfin, les vasopresseurs sont introduits parallèlement. La noradrénaline est utilisée comme agent de premier choix sauf si le patient présente une bradycardie symptomatique. ${ }^{33}$

Si ces étapes conduisent avec succès à la restauration de la pression artérielle et que le mécanisme du choc est évident, le patient doit alors être étroitement surveillé. Si, en revanche, cette approche échoue et que le soutien vasoactif doit être augmenté, un examen échographique au chevet du patient devrait alors être pratiqué, ${ }^{12}$ comme cela sera décrit dans le deuxième module de DPC de cette série en deux parties sur l'instabilité hémodynamique. 


\section{Cas clinique}

Une femme diabétique de 67 ans, pesant $48 \mathrm{~kg}$, souffrant d'une maladie pulmonaire obstructive chronique et d'une coronaropathie se présente à l'hôpital avec un syndrome abdominal aigu. Un diagnostic de perforation intestinale avec péritonite est confirmé par la tomographie. Dans la salle d'opération, après l'induction de l'anesthésie à l'aide d'accès artériels et veineux périphériques appropriés, la pression artérielle systolique est de $80 \mathrm{mmHg}$ avec une fréquence cardiaque de 110 battements $\cdot \mathrm{min}^{-1}$. La patiente répond à l'administration de liquide et reste stable pendant toute la procédure. Cependant, à la fin de l'intervention et pendant la fermeture de l'abdomen, elle devient hypotendue et ne répond plus à l'administration de liquides. La noradrénaline est débutée et malgré des doses croissantes, sa pression artérielle systolique reste à $85 \mathrm{mmHg}$. La valeur de l'ETCO2 est de $37 \mathrm{mmHg}$ avec une ventilation minute de $6 \mathrm{~L} \mathrm{~min}^{-1}$.

\section{Directives pour compléter le module de développement professionnel continu (DPC):}

1. Lisez l'article actuel et les références indiquées en gras.

2. Allez à la page http://www.cas.ca/Members/CPDOnline et sélectionnez le module actuel (Approches clinique et échographique du choc au chevet dupatient - Partie 1: L'approche clinique).

3. Répondez aux questions à choix multiple concernant le scénario du cas.

4. Après avoir saisi toutes vos réponses, vous aurez accès aux explications des experts sur tous les choix possibles.

5. Les participants peuvent réclamer jusqu'à quatre heures de DPC, pour un total de 12 crédits au titre de la section 3 du programme de DPC du Collège royal des médecins et chirurgiens du Canada.

Acknowledgements The authors sincerely thank France Thériault and Denis Babin for their help in the completion of the manuscript.

Funding sources Montreal Heart Institute Foundation.

Remerciements L'auteur remercie sincèrement France Thériault et Denis Babin pour leur contribution à l'achèvement du manuscrit.

Sources de financement Fondation de l'Institut de cardiologie de Montréal.

Conflits d'intérêts Aucun déclaré.

\section{References}

Note that references 35 to $\mathbf{4 2}$ are cited in the Clinical Case Question and Answers section of the CPD module that is available to CJA subscribers at http://www.cas. ca/Members/CPDOnline.

1. Walsh M, Devereaux PJ, Garg AX, et al. Relationship between intraoperative mean arterial pressure and clinical outcomes after noncardiac surgery: toward an empirical definition of hypotension. Anesthesiology 2013; 119: 507-15.

2. Bijker JB, Persoon S, Peelen LM, et al. Intraoperative hypotension and perioperative ischemic stroke after general surgery: a nested case-control study. Anesthesiology 2012; 116: 658-64.

3. Aronson $S$, Phillips-Bute B, Stafford-Smith $M$, et al. The association of postcardiac surgery acute kidney injury with intraoperative systolic blood pressure hypotension. Anesthesiol Res Pract 2013; 2013: 174091.

4. Monk TG, Saini V, Weldon BC, Sigl JC. Anesthetic management and one-year mortality after noncardiac surgery. Anesth Analg 2005; 100: 4-10.

5. Rao V, Ivanov J, Weisel RD, Ikonomidis JS, Christakis GT, David $T E$. Predictors of low cardiac output syndrome after coronary artery bypass. J Thorac Cardiovasc Surg 1996; 112: 38-51.

6. Denault AY, Tardif JC, Mazer CD, Lambert J; BART Investigators. Difficult and complex separation from cardiopulmonary bypass in high-risk cardiac surgical patients: a multicenter study. J Cardiothorac Vasc Anesth 2012; 608-16.

7. Bijker JB, van Klei WA, Vergouwe $Y$, et al. Intraoperative hypotension and 1-year mortality after noncardiac surgery. Anesthesiology 2009; 111: 1217-26.

8. Barbosa RR, Rowell SE, Fox EE, et al. Increasing time to operation is associated with decreased survival in patients with a positive FAST examination requiring emergent laparotomy. J Trauma Acute Care Surg 2013; 75(1 Suppl 1): S48-52.

9. Kumar A, Roberts D, Wood KE, et al. Duration of hypotension before initiation of effective antimicrobial therapy is the critical determinant of survival in human septic shock. Crit Care Med 2006; 34: 1589-96.

10. Rathore SS, Curtis JP, Chen J, et al. Association of door-toballoon time and mortality in patients admitted to hospital with ST elevation myocardial infarction: national cohort study. BMJ 2009; 338: b1807.

11. Marler JR, Tilley BC, Lu $M$, et al. Early stroke treatment associated with better outcome: the NINDS rt-PA stroke study. Neurology 2000; 55: 1649-55.

12. Vincent JL, De Backer D. Circulatory shock. N Engl J Med 2013; 369: 1726-34.

13. Denault $A Y$. Intraoperative Hemodynamic Instability During and After Separation From Cardiopulmonary Bypass: Importance, Mechanism and Prevention. PhD Thesis - Université de Montréal, 2010. Available from URL: https://papyrus.bib.umontreal.ca/ xmlui/handle/1866/4241 (accessed May 2014).

14. Deslauriers N, Dery $R$, Denault A. Acute abdominal compartment syndrome. Can J Anesth 2009; 56: 678-82.

15. Jacobsohn E, Chorn $R$, O'Connor M. The role of the vasculature in regulating venous return and cardiac output: historical and graphical approach. Can J Anaesth 1997; 44: 849-67.

16. Funk DJ, Jacobsohn E, Kumar A. The role of venous return in critical illness and shock-part I: physiology. Crit Care Med 2013; 41: 255-62. 
17. Denault AY, Chaput $M$, Couture P, Hebert $Y$, Haddad $F$, Tardif $J C$. Dynamic right ventricular outflow tract obstruction in cardiac surgery. J Thorac Cardiovasc Surg 2006; 132: 43-9.

18. Rochon AG, L'Allier PL, Denault AY. Always consider left ventricular outflow tract obstruction in hemodynamically unstable patients. Can J Anesth 2009; 56: 962-8.

19. Toupin F, Denault A, Lamarche $Y$, Deschamps A. Hemodynamic instability and fluid responsiveness. Can J Anesth 2013; 60: 12407.

20. Prkno A, Wacker C, Brunkhorst FM, Schlattmann P. Procalcitonin-guided therapy in intensive care unit patients with severe sepsis and septic shock - a systematic review and metaanalysis. Crit Care 2013; 17: R291.

21. Denault AY, Haddad F, Jacobsohn E, Deschamps A. Perioperative right ventricular dysfunction. Curr Opin Anaesthesiol 2013; 26: 71-81.

22. Breithardt $G$, Breithardt OA. Left bundle branch block, an oldnew entity. J Cardiovasc Transl Res 2012; 5: 107-16.

23. Nilsson LM. Respiration signals from photoplethysmography. Anesth Analg 2013; 117: 859-65.

24. Grocott HP, Gulati H, Srinathan S, Burkhard Mackensen G. Anesthesia and the patient with pericardial disease. Can J Anesth 2011; 58: 952-66.

25. Kodali BS. Capnography outside the operating rooms. Anesthesiology 2013; 118: 192-201.

26. Beigel R, Cercek B, Luo H, Siegel RJ. Noninvasive evaluation of right atrial pressure. J Am Soc Echocardiogr 2013; 26: 1033-42.

27. Denault A, Deschamps A, Murkin JM. A proposed algorithm for the intraoperative use of cerebral near-infrared spectroscopy. Semin Cardiothorac Vasc Anesth 2007; 11: 274-81.

28. Parnia $S$, Nasir A, Ahn A, et al. A feasibility study of cerebral oximetry during in-hospital mechanical and manual cardiopulmonary resuscitation. Crit Care Med 2014; 42: 930-3.

29. Harel F, Denault A, Ngo Q, Dupuis J, Khairy P. Near-infrared spectroscopy to monitor peripheral blood flow perfusion. J Clin Monit Comput 2008; 22: 37-43.

30. Dorman T, Breslow MJ, Lipsett PA, et al. Radial artery pressure monitoring underestimates central arterial pressure during vasopressor therapy in critically ill surgical patients. Crit Care Med 1998; 26: 1646-9.
31. Denault A, Deschamps A. Abnormal aortic-to-radial arterial pressure gradients resulting in misdiagnosis of hemodynamic instability. Can J Anesth 2009; 56: 534-6.

32. Bagshaw SM, Chawla LS. Hydroxyethyl starch for fluid resuscitation in critically ill patients. Can J Anesth 2013; 60: 709-13.

33. De Backer D, Biston P, Devriendt J, et al. Comparison of dopamine and norepinephrine in the treatment of shock. N Engl J Med 2010; 362: 779-89.

34. Denault AY, Couture P, Vegas A, Buithieu J, Tardif JC. Transesophageal Echocardiography Multimedia Manual Second edition - A Perioperative Transdisciplinary Approach. New York: Informa Healthcare; 2011.

35. Mingo S, Benedicto A, Jimenez MC, Perez MA, Montero M. Dynamic left ventricular outflow tract obstruction secondary to catecholamine excess in a normal ventricle. Int J Cardiol 2006; 112: 393-6.

36. Dellinger RP, Levy MM, Carlet JM, et al. Surviving Sepsis Campaign: international guidelines for management of severe sepsis and septic shock: 2008. Crit Care Med 2008; 36: 296-327.

37. Michard F, Teboul JL. Predicting fluid responsiveness in ICU patients: a critical analysis of the evidence. Chest 2002; 121: 2000-8.

38. Vieillard-Baron A, Caille $V$, Charron $C$, Belliard $G$, Page B, $J a r d i n ~ F$. Actual incidence of global left ventricular hypokinesia in adult septic shock. Crit Care Med 2008; 36: 1701-6.

39. Malbrain ML, Chiumello D, Pelosi $P$, et al. Incidence and prognosis of intraabdominal hypertension in a mixed population of critically ill patients: a multiple-center epidemiological study. Crit Care Med 2005; 33: 315-22.

40. Malbrain ML, Cheatham ML, Kirkpatrick A, et al. Results from the International Conference of Experts on Intra-abdominal Hypertension and Abdominal Compartment Syndrome. I. Definitions. Intensive Care Med 2006; 32: 1722-32.

41. Cheatham $M L$, Malbrain ML, Kirkpatrick A, et al. Results from the International Conference of Experts on Intra-abdominal Hypertension and Abdominal Compartment Syndrome. II. Recommendations. Intensive Care Med 2007; 33: 951-62.

42. Landry $D W$, Oliver JA. The pathogenesis of vasodilatory shock. N Engl J Med 2001; 345: 588-95. 